\author{
UNIVERSIDADE DE SÃO PAULO \\ FACULDADE DE FILOSOFIA, LETRAS E CIÊNCIAS HUMANAS \\ DEPARTAMENTO DE CIÊNCIA POLÍTICA \\ PROGRAMA DE PÓS-GRADUAÇÃO EM CIÊNCIA POLÍTICA
}

MARIANA MAIA RUIVO

Opinião Pública e Política Externa: criação de uma tipologia brasileira.

São Paulo 


\title{
Opinião Pública e Política Externa: criação de uma tipologia brasileira.
}

\author{
Dissertação apresentada ao \\ Departamento de Ciência Política da \\ Universidade de São Paulo para \\ obtenção do título de Mestra em \\ Ciência Política. \\ Área de concentração: Ciência \\ Política \\ Orientador: Prof. Dr. Amâncio Jorge \\ Silva Nunes de Oliveira.
}


Autorizo a reprodução e divulgação total ou parcial deste trabalho, por qualquer meio convencional ou eletrônico, para fins de estudo e pesquisa, desde que citada a fonte. 
Nome: RUIVO, Mariana Maia

Título: Opinião Pública e Política Externa: criação de uma tipologia brasileira.

Dissertação apresentada ao Departamento de Ciência Política da Universidade de São Paulo para obtenção do título de Mestra em Ciência Política.

Aprovada em:

Banca Examinadora

$\operatorname{Profr}(\mathrm{a}) \cdot \operatorname{Dr}(\mathrm{a})$. Instituição:

Julgamento: Assinatura:

$\operatorname{Prof}(\mathrm{a}) . \operatorname{Dr}(\mathrm{a})$. Instituição:

Julgamento: Assinatura: 
À Marília Pereira Maia Ruivo

Ao José Jaime Ruivo

À Maria da Glória Pereira Maia (in memorian) Ao Moair de Souza Maia (in memorian) 


\section{Agradecimentos}

Ao meu orientador, prof. Dr. Amâncio Jorge Nunes de Oliveira, que me tirou da "zona de conforto", lançou o desafio e aqui está o resultado. Meu eterno agradecimento e gratidão pela paciência, atenção e equilíbrio, principalmente quando o desespero falou mais alto do que a razão. Foi um enorme prazer e privilégio tê-lo como professor, tutor e orientador.

Ao prof. Dr. Flávio Rocha de Oliveira, meu ex-orientador, que em março de 2008 escreveu que tinha esperança de que eu conseguisse me encontrar "aqui ou alhures. De preferência aqui, onde o peso do chicote termina cedendo lugar à suavidade da pele". Pois digo que, quase 7 anos depois, me encontrei aqui, na Ciência Política e sigo nesse caminho... Porém, ainda na esperança de que realmente o peso do chicote dê lugar à suavidade da pele. Minha mais sincera e eterna gratidão.

Ao prof. Dr. Héctor Saint-Pierre, que se transformou em um grande amigo e foi essencial para manter a sanidade dessa pesquisadora. Obrigada pelo apoio, pelas conversas e, acima de tudo, pela paciência.

À profa. Dra. Elizabeth Balbachevsky, que com seu jeito meigo, sempre alegre e prestativa, ajudou e muito no desenvolvimento dessa pesquisa. Tenho certeza que nos encontraremos em muitas cavalgadas!

À profa. Dra. Janina Onuki, pelos ensinamentos, paciência, ajuda, calma e conselhos. Além das aulas, sua atenção e carinho foram fundamentais para a conclusão do trabalho e para a minha formação acadêmica.

Ao prof. Dr. Rogério Arantes, pelas conversas, pelos conselhos e atenção, com a certeza que ainda iremos muitas vezes ao Morumbi prestigiar o nosso tricolor. Leve à sua família o meu carinho.

Ao prof. Dr. Wagner Pralon Mancuso, que além de ter sido o portador de uma das melhores notícias que recebi, a aprovação no mestrado, foi um grande amigo, com conselhos, conversas, dicas e horas discutindo tipologia.

Aos profs Dr. Rafael Villa, Dra. Lorena Barberia, Dr. Peter Demant, Dra. Rossa Reis, Dr. João Paulo Veiga, pelas aulas e ensinamentos e demais professores do DCP/USP.

À secretaria do Departamento de Ciência Política da Universidade de São Paulo, representada nas figuras de Rai, Marcia, Vasne, Ana e Leo vocês, juntos, formam o coração do DCP. E, posso garantir, é a melhor equipe de todas! 
Aos pesquisadores do Centro de Estudo das Negociações Internacionais - CAENI/IRI/USP, em especial ao Rafael Nunes Magalhães e prof. Dr. Pedro Feliú Ribeiro, vocês salvaram minha vida quando entrei em conflito com o SPSS. Obrigada e obrigada!

À Coordenação de Aperfeiçoamento de Pessoal de Nível Superior (Capes) pelo apoio financeiro e possibilidade de me dedicar exclusivamente à pesquisa.

Aos colegas de mestrado, principalmente à Barbara Vieira, que é um exemplo de dedicação, seriedade e profissionalismo. Ao Guilherme Nicolau e Renata Costa, pelas risadas e boas conversas. E Marsílea Gombata, competente jornalista e que foi conquista pela Ciência Política. Tenho certeza que nos reencontraremos um dia.

Aos alunos de Análise de Política Externa (noturno) - turma T11 (20122015), do curso de Relações Internacionais da Universidade de São Paulo, que me receberam como monitora e muito me ensinaram. Em especial à quatro alunos: Mauro Kitti - que já fomos colegas de turma no curso de pósgraduação em Política e Relações Internacionais e hoje seguimos juntos na academia - , Raimundo Oliveira Filho, José Almir de Alcântara, que também já foi colega de turma, junto com o Mauro no curso de pós-graduação e ao Afonso Cavalcanti. Vocês são especiais... e obrigada por todo apoio dado a essa monitora!

Aos amigos(as) virtuais que com palavras de apoio, força e sempre o desejo de boa sorte ajudaram quando o desânimo e o cansaço estiveram presentes durantes esses dois anos. Principalmente aos queridos e também amigos prof. Dr. Alex Jobim e prof. Dr. André Varella.

Aos meus grandes amigos, Antônio Gouvêa, Bruna Adele e Mariana Vieira e sua pequena Eva (ordem alfabética, mas com igual amor). Vocês foram minha base e meu suporte quando a vida se tornou dura e injusta, e me deram a mão e me mantiveram em pé. Vocês são os melhores amigos do mundo! Obrigada, obrigada e obrigada!

Aos tios, tias, primos e primas, que mesmo à distância torceram por mim e estiveram ao meu lado. Principalmente à Manuella Maia Ribeiro, doutoranda, prima e que me acompanha nessa jornada acadêmica. Ao tio Mario Eduardo Ruivo, que com seu jeito 'Ruivo' de ser e sua preocupação e cuidado, me deu todo apoio e ajuda possível. À Dra. Lucimar Ruivo, prima e médica que sempre com muito carinho, sorriso estampado no rosto e atenção deu suporte à mim e ao meu pai quando precisamos.

Em especial ao meu tio-avô prof. Dr. Almir de Souza Maia, que por muitos anos ocupou a cadeira de reitor da Universidade Metodista de 
Piracicaba, é um exemplo de profissional e ser humano. Obrigada por cada palavra, por todo apoio e pela torcida. Essa simples pesquisadora e cientista política tem muito orgulho em ser sua sobrinha.

E, por último, mas com maior importância, à minha família...

Aos meus irmãos, Marcius e Jaime Júnior, pela torcida e suporte e minha irmã Marcella e meu cunhado Francisco (extensivo à sua família e principalmente sua mãe, D. lêda), que além disso, estão me dando um grande presente, minha sobrinha e afilhada Maria Eduarda. Obrigada a vocês que seguraram a barra quando não pude estar presente.

Aos meus pais, Marília Pereira Maia Ruivo e José Jaime Ruivo, que me deram todo o suporte necessário para fazer o mestrado e, são exemplos de força, perseverança e humanidade. Muitas vezes a saudade era grande e a vontade de desistir batia à porta, e foi por vocês que me mantive em pé e seguindo em frente, lutando para ser motivo de orgulho! Vocês são meus pilares, meus guias e protetores. Minha eterna gratidão!

À tod@s que direta ou indiretamente me ajudaram, meu muito obrigada! A jornada foi concluída graças ao apoio de vocês! 
"As opiniões não são inatas, nem surgem do nada. A questão "o que é opinião pública?" é melhor respondida através de três processos e na seguinte ordem: (a) a disseminação de opiniões a partir de níveis da elite; (b) 0 borbulhar de opiniões a partir das bases; e (c) identificações com grupos de referência".

(SARTORI, 1994, p. 132) 
Resumo

A finalidade dessa dissertação de mestrado é apresentar uma proposta de criação de tipologia da Opinião Pública em relação à Política Externa Brasileira. Para isso, foi utilizada a pesquisa survey "Opinião Pública - o Brasil, a América e o Mundo", realizada em 2011 pelo Centro de Investigación y Docencia Económicos - CDE em parceria com o Instituto de Relações Internacionais da Universidade de São Paulo - IRI/USP. E, para a criação da tipologia, foi usada como base a pesquisa de Eugene Wittkof, Faces of Internacionalism Public Opinion in American Foreign Policy (1990), onde abordou os padrões das elites e da massa em relação ao grau de apoio ao envolvimento internacional dos Estados Unidos. Dessa forma, foi criado quatro grupos de atitude em Política Externa: Isolacionista, Internacionalista, Conciliadores e Intervencionista. Para criar a tipologia brasileira, os grupos foram adaptados para a realidade do país e foram recriados: Isolacionista, Internacionalista Soft Line, Internacionalista Moderado e Internacionalista Hard Line. O presente trabalho tomará como base algumas perspectivas teóricas do debate de Análise de Política Externa e de Opinião Pública, com o intuito de buscar entender como a sociedade brasileira - opinião pública - se posiciona em relação à postura do Brasil no sistema internacional, através de sua política externa. Para efeito de análise, dois temas foram pré-selecionados, sobre violação de direitos humanos e em caso de golpe contra um governo democraticamente eleito, todos em relação à outro Estado. Além da criação de uma tipologia brasileira, foi realizado o cruzamento entre algumas variáveis para caracterizar os grupos tipológicos. De maneira ampla, os resultados encontrados mostraram que a maioria da opinião pública defende uma postura mais internacionalista moderada do Brasil no Sistema Internacional.

Palavras - chave:

Opinião Pública - Política Externa Brasileira - Tipologia 
Abstract

The purpose of this master thesis is to present a proposal for a typology of creating public opinion in relation to the Brazilian Foreign Policy. Within this regard, it is applied the survey "Public Opinion - Brazil, America and the World"(held in 2011 by the Centre de Investigación y Docencia Economic - CDE in partnership with the International Relations Institute of the University of São Paulo - IRI / USP), was applied. In order to create a typology, research of Eugene Wittkof, Faces of Internationalism Public Opinion in American Foreign Policy (1990). This research had been addressed the standards of the elites and the mass in relation to the degree of support for international involvement USA. Thus, it was created four attitude groups in Foreign Policy: isolationist, Internationalist, conciliators and Interventional. In order to create the Brazilian typology groups, theses groups have been adapted to the reality of the country as isolationist, Internationalist Soft Line, Internationalist Moderate and Hard Line. The bases of this work it is related to some theoretical perspectives of Foreign Policy Analysis and discussion of public opinion. The main goal is to try to understand how the Brazilian society - public opinion - it is positioned in relation to Brazil's standards in the international system, through its foreign policy. For purposes of analysis, two topics are selected. The first one is about violation of human rights and the second one, supposing that a coup against a democratically elected government occurs (in relation to another State). It was necessary, to understand the structure of these typological groups. Therefore a cross checking among the variables was realized. Broadly, the results demonstrate that the majority of public opinion advocates to moderate internationalist group, in Brazil in the International System.

Key words

Public Opinion - Brazilian Foreign Policy - Typology 
Sumário

Introdução 15

Capítulo 1 Opinião Pública, Opinião de Elite e Política Externa 26

1.1Pré-definição sobre Opinião Pública 26

1.2 A história da Opinião Pública 27

1.3 Os primeiros estudos sobre Opinião Pública 29

1.4 Teorias sobre Opinião Pública no século XIX 32

$1.5 \mathrm{O}$ debate contemporâneo sobre Opinião Pública 36

1.6 Opinião Pública X Opinião de Elite em Política Externa 45

1.7 Opinião Pública e Política Externa Brasileira 51

Capítulo 2 Criando uma tipologia da Opinião Pública sobre a Política Externa Brasileira 55

2.1 Tipologia brasileira 59

2.2 Relação Variáveis Dependentes e Independentes - caracterizando os grupos tipológicos

Conclusão 80

Referências Bibliográficas 85 

Introdução

A discussão de opinião pública gera um grande debate no meio acadêmico e político, sendo alvo de fortes críticas durante os séculos XIX e XX, voltadas, principalmente, para a 'ignorância' política dos cidadãos e de uma suposta inconstância, por ser alvo de influência da mídia. Para George Bishop, em seu trabalho "The Illusion of Public Opinion” (2005), a opinião pública é uma ilusão que se perpetra pelas sondagens e que se tornou, mais frequente, não somente devido à proliferação das sondagens financiadas pela mídia de massas, mas também devido a problemas crônicos na realização de tais sondagens. Porém, para Bourdieu (1981), “a opinião pública não existe”.

Se a opinião pública já é alvo de críticas quando relaciona seu uso como um decision input para políticas públicas, elas se tornam mais enfáticas quando se trata de política externa. Para a Teoria Realista das Relações Internacionais, o Estado é o ator central do sistema e a ação externa de cada país é orientada pelo interesse nacional. Em contraponto, surge o campo da Análise de Política Externa (APE), que investiga a influência que a formulação da agenda de política externa sofre dos atores domésticos. Assim, além de analisar o perfil do tomador de decisão, a APE busca compreender a estrutura do processo decisório e quais os atores o influenciam; entre eles, a opinião pública.

Charles Hermann chama a política externa como um "conceito negligenciado" (apud NEACK, 2008: 09). Ele afirma que esta negligência tem sido um dos obstáculos mais sérios para fornecer explicações mais adequadas e abrangentes da política externa (NEACK, 2008: 09). Para Hermann parte da 
razão para essa negligência esta ligada ao fato de " most people dealing with the subject have felt confident that they knew what foreign policy was." Em última análise, define a política externa como um comportamento do Estado, e "the discrete purposeful action that results from the political level decision of an individual or group of individuals... [it is] the observable artifact of a political level decision. It is not the decision, but a product of the decision." (apud Neack, 2008: 09)

De acordo com Laura Neack (2008), a política externa de um Estado é feita e realizada em um ambiente complexo, tanto nacional quanto internacionalmente e seus resultados surgem a partir de trabalhos de coligações domésticas com atores e grupos internacionais. As questões de política externa derivam, muitas vezes, de questões de política interna e para realizar uma análise de política externa é necessário que ela seja multinível e multifacetada, a fim de confrontar as fontes complicadas e natureza da política externa.

O estudo da opinião pública e sua relação com a política externa surgiu nos Estados Unidos na década de 1940, com a preocupação de entender qual papel o país deveria ocupar com o fim da II Guerra Mundial, assumindo uma postura internacionalista mais atuante, buscando a preservação de sua liderança no cenário internacional ou um comportamento isolacionista. Após esse período, uma segunda fase desse estudo tem inicio durante 0 prolongamento da Guerra do Vietnã, quando o questionamento era a cerca das premissas, descobertas e proposições da análise de opinião pública do período (Holsti, 2004). 
Nas Relações Internacionais, são limitados os estudos voltados à opinião pública e política externa, e normalmente, referem-se à interconexão entre a esfera doméstica e a internacional. De acordo com Rosenau (1967), tendem a focar o impacto dos atores domésticos na formulação da política externa. Assim, prossegue o autor, a política externa seria uma resposta aos estímulos internacionais, sendo constituída no plano doméstico por forças sociais que contribuem para a qualidade e comportamento do Estado no sistema internacional. Na grande maioria dos estudos o comportamento dos atores ficam em destaque, assim como suas visões e estratégias quanto à formulação e implementação da política exterior. São levantados fatores como ideias, visões, percepções na tentativa de explicar os comportamentos e a influência que os atores internos exercem na política externa.

Algumas teorias das Relações Internacionais buscam, também, explicar essa relação entre a política externa de um Estado e sua política doméstica. Um grande exemplo, e talvez o mais discutido, é a teoria realista, que toma como base os estudos de Tucídides, Hobbes, Maquiavel e Morgenthau, sobre o papel exercido pelo Estado, sendo ele o principal ator. Para os realistas, o Estado seria como uma "caixa-preta", fazendo com que seja "abstraído os processos internos de tomada de decisão e as motivações políticas que levam os Estados a agir no plano internacional" (Nogueira \& Messari, 2005: 25). Vale ressaltar que para essa corrente, o Estado é um ator unitário e racional, agindo de forma uniforme e homogênea e sempre em defesa do interesse nacional. Para Morgenthau (2003), a racionalidade que se exige uma boa política externa não suportaria as preferências da Opinião Pública, que ele considera mais emocionais do que racionais. 
Mas, a partir da década de 1970, o pressuposto do ator unitário e racional começa a ser questionado e o Estado se torna descentralizado na autoridade e surgem múltiplos atores considerados indispensáveis aos processos internacionais, influenciando cada vez mais nos processos de política externa. Nessa visão liberal, busca-se compreender as estruturas políticas domésticas e seus canais de acesso, principalmente ao considerar que diferentes tipos de estrutura favorecem ou não a participação dos atores sociais ao se formular a agenda de política externa, tendo consequências nas visões e atitudes dos atores estatais e não-estatais (Goldstein e Keohane, 1993; Katzenstein, 1976; Rissen-Kapen, 1995).

Na perspectiva liberal, há uma busca pela maximização racional dos interesses de indivíduos e grupos sociais. O liberalismo utilitarista, de acordo com Rittberger (2004), também caracteriza os atores internacionais como egoístas, sendo que, neste quadro teórico, são considerados atores: indivíduos e grupos domésticos ou internacionais, eleitores, grupos de interesse, partidos políticos, políticos e burocratas. Assim, a política externa de um Estado, para os liberais, nada mais é do que a representação dos interesses dos grupos sociais mais poderosos.

Uma terceira linha teórica das Relações Internacionais e que merece ser destacada é o Realismo Neoclássico ${ }^{1}$, que surge como uma combinação entre as teorias realista e neo-realista, e sustenta que as ações de um Estado na arena internacional podem ser explicadas por variáveis sistêmicas, cognitivas e

\footnotetext{
${ }^{1}$ Para maiores informações, ver: LOBELL, S.; RIPSMAN, N. \& TALLIAFERRO, J. Neoclassical Realism, the State and Foreign Policy. Cambrigde.
} 
domésticas, que afetam o poder e a liberdade de ação dos tomadores de decisão na política externa.

Dessa forma, nas Relações Internacionais, os estudos sobre a relação entre opinião pública e política externa fazem interconexão entre os assuntos domésticos e internacionais, que, segundo Rosenau (1967) tendem a focalizar o impacto dos atores domésticos na formulação da política externa. Assim, continua o autor, a política externa de um país seria uma simples resposta a uma série de estímulos internacionais, sendo também constituídas, internamente, por forças sociais que contribuem para a qualidade e o conteúdo do comportamento do Estado no sistema internacional (Rosenau, 1967:2).

Analisar o comportamento dos atores, tais como suas visões e suas estratégicas em relação à formulação e implementação da política externa é o que predomina nessa área de estudo. Esses fatores são importantes para explicar como os agentes se comportam e a influência que os atores domésticos exercem na política externa do Estado. Nessas interações, os elementos centrais são as preferências e os valores das elites e da massa sobre a política exterior, como o papel da mídia e a formação de grupos de interesse.

Assim, como os fatores políticos ideológicos e seus impactos na política externa, o processo de tomada de decisão nas ações externas e sua interconexão com o ambiente social também são considerados objetos de análises da relação dos fatores domésticos e da política externa do país. A análise de estruturas domésticas permite a identificação dos vetores de força e autonomia do Estado em face da sociedade no processo de política externa. 
De acordo com Katzenstein (1976), é necessário observar o quanto a política externa é permeável aos interesses dos atores domésticos, transpondo pela compreensão dos processos que estão interconectados no interior da sociedade.

O papel dos atores sociais e seu impacto na política externa é um dos temas mais controversos na literatura das relações internacionais. Não há um consenso a respeito da sociedade e seu provável efeito nas decisões em política externa. Putnam (1998) parte da perspectiva de um modelo denominado "jogos dos dois níveis", onde considera a atuação externa dos Estados a partir de dois níveis - doméstico e internacional. No nível nacional, os atores domésticos fazem pressão no governo para adotar políticas favoráveis. No nível internacional, na tentativa de satisfazer os grupos domésticos, o governo tende a limitar os impactos externos prejudiciais. Nesse modelo, a população em geral exerce um papel secundário, quando comparada à burocracia, à elite e diversos grupos de interesses (Putnam, 1998), repercutindo nas visões negativas sobre a participação da sociedade, em geral, nos temas de política externa.

É expressiva a quantidade de trabalhos que relacionam as decisões políticas e as atitudes da sociedade nos processos internacionais, como, Holsti, (1996) e Folye (1997). Para Holsti (1996), por exemplo, o público de massa não possuía atitudes em relação à política internacional. Pesquisas realizadas durante os anos 1950 e 60, principalmente nos Estados Unidos, apoiam que o público, mal informado, teve pouco impacto sobre a política externa. 
Até pouco tempo, temas de política externa estavam limitados aos órgãos responsáveis pela sua formulação e execução, como o Itamaraty e, num menor protagonismo, à Presidência da República. Aos poucos, tais assuntos começaram a fazer parte dos debates eleitorais, onde decisões tomadas em arena internacional, sobretudo em temas com impacto distributivo, tinham impacto direto na vida nacional. Nos últimos 20 anos, o Brasil ampliou, de forma significativa, sua presença no mundo e em arenas multilaterais. Assumindo uma postura mais ativa, o país passou a exercer papel crescente e de relevante importância nos grandes centros de discussão e decisão internacional, ganhando cada vez mais destaque e exigindo diferentes posturas.

As transformações da política externa brasileira tiveram início com a mudança de regime, a partir de 1985, e com o advento da 'diplomacia presidencial', inicialmente com o ex-presidente Fernando Henrique Cardoso (1995-2002), que implementou uma política exterior voltada para adesão aos regimes internacionais, denominada como "autonomia pela participação" ( Vigevani \& Cepaluni, 2007), caracterizada por uma política de "cunho liberal, sem a perda da capacidade de gestão da política externa" (Vigenvani \& Cepaluni, 2007: 283). A agenda internacional do governo FHC teve como objetivo "influenciar a própria formulação dos princípios e das regras que regem o sistema internacional" (Vigevani \& Capeluni, 2007: 283)

Com uma política externa que priorizava a reforma de instituições de governança global, Luiz Inácio Lula da Silva (2003 -2010) buscou alianças multilaterais, com potências regionais e parceiros não tradicionais, como China, África, Oriente Médio e Europa Oriental. Além disso, foi pautada numa agenda 
política de projeção do Brasil na América do Sul. De acordo com Vigevani \& Cepaluni (2007), foi uma política de "autonomia pela diversificação", pois acreditava-se que haveria uma redução das "assimetrias nas relações externas com países mais poderosos" (2007: 283) e, assim, aumentaria a "capacidade negociadora nacional" (2007: 283). Foi nesse período que temas de política externa ganharam maior destaque no debate nacional e, por consequência, a opinião pública pode ser considerada um key driver para a condução e manutenção de qualquer regime político.

Numa democracia, isso fica mais evidente; mas até mesmo os regimes autoritários estão sujeitos a protestos, insurgências ou revoltas. Um bom exemplo foi a "Primavera Árabe", que aconteceu nos países do Oriente Médio e Norte da África, onde uma onda revolucionária de manifestações e protestos contra regimes autoritários ocorreram entre 2010 e 2011. Segundo Napoleão Bonaparte (apud Marinheiro, 2012), "a opinião pública é uma força misteriosa e invisível, à qual tudo deve ceder. Não há nada mais instável, mais vago ou mais poderoso; ainda inconstante como se apresenta, é, no entanto, muito mais frequentemente verdadeira, razoável e justo do que imaginamos". E, completa, "a opinião pública é o termômetro que o monarca deveria consultar constantemente". Ou seja, ela pode ser determinante para o processo decisório, em quais políticas públicas possuem maior chance de acerto e eficácia.

O presente trabalho tomará como base algumas perspectivas teóricas, do debate de Análise de Política Externa e de Opinião Pública, com o intuito de buscar entender como a sociedade brasileira - opinião pública - se posicionam em relação à postura do Brasil no sistema internacional, através de sua política 
externa. Para isso, será utilizada a pesquisa quantitativa, "Brasil, as Américas e o Mundo", realizada em 2011. Esse survey faz parte do projeto "Las Americas y el Mundo", liderado por pesquisadores do Centro de Investigación y Docencia Económicos - CDE, no México, em parceria com alguns institutos acadêmicos ${ }^{3}$ da América Latina, entre eles, o Instituto de Relações Internacionais da Universidade de São Paulo- IRI/USP. O intuito das pesquisas realizadas em 2010/2011, através de questionários, é colher informações sobre opiniões, atitudes, crenças, interesses, aspirações e valores de lideranças e cidadãos comuns sobre suas relações com o mundo. No Brasil, duas pesquisas foram realizadas, uma com a população em geral, e outra com um grupo classificado com elite ${ }^{4}$

A pesquisa survey "Brasil, as Américas e o Mundo - Opinião Pública", aplicada com 2.000 pessoas, em todas as regiões do Brasil, com mulheres e homens, com idade igual ou superior à 18 anos. O procedimento da seleção da amostra foi dividido em três principais estágios: $1^{\circ}$ ) sorteio dos municípios; $2^{\circ}$ ) sorteio dos setores censitários e $3^{\circ}$ ) sorteio dos domicílios/pessoas. As 2.000 entrevistas realizadas foram distribuídas proporcionalmente à população em três grandes categorias: cidades do interior, capitais e nas regiões metropolitanas, de acordo com a tabela a seguir:

\footnotetext{
2 "Sua aplicação foi realizada pela Techné - Informática e Recursos Humanos, sob a direção de Amaury de Souza, para a amostra de líderes, e pela IPSOS Opinion para o público. Nenhuma das duas empresas têm responsabilidade pela interpretação dos dados, realizada pelos pesquisadores do IRI-USP". (Almeida,Onuki \& Pique, s/d: 07)

${ }^{3}$ Além do CIDE e do IRI/USP, as outras instituições participantes foram a Universidad de Los Andes - Colômbia; a Facultad Latinoamericana de Ciencias Sociales - FLACSO - Equador e o Instituto de Opinión Pública y La Escuela de Goberno da Pontificia universidad Católica de Peru.

${ }^{4} \mathrm{O}$ intuito inicial da dissertação seria realizar uma comparação tipológica entre a Opinião Pública e Opinião de Elite. Porém, com o avanço das pesquisas a criação de uma tipologia sobre a Opinião de Elite não foi possível, sendo decido limitar à Opinião Pública.
} 


\begin{tabular}{|l|c|}
\hline \multicolumn{1}{|c|}{ Região } & N $^{\circ}$ Entrevistas \\
\hline Norte / Centro - Oeste & 180 \\
\hline Nordeste & 520 \\
\hline Sudeste & 1020 \\
\hline Sul & 280 \\
\hline TOTAL & $\mathbf{2 0 0 0}$ \\
\hline
\end{tabular}
Fonte: O Brasil, as Américas e o Mundo - 2011 (Opinião Pública)

O presente trabalho tem como propósito criar uma tipologia brasileira sobre Opinião Pública, com base nos estudos de Eugene Wittkopf, em sua obra Faces of Internationalism Public Opinion in American Foreign Policy (1990), onde abordou os padrões das elites e da massa em relação ao grau de apoio ao envolvimento internacional dos Estados Unidos. Ao analisar pesquisas $^{5}$ realizadas entre os anos de 1974 e 1986, em intervalos de 4 anos, durante a Guerra Fria, o autor demostra que as análises não poderiam ser limitadas à dicotomia 'cooperativa' e 'militarista', que seriam duas formas de internacionalismo. Assim, foram criados quatro grupos de atitude em Política Externa: Internacionalista, Isolacionista, Conciliadores e Intervencionista.

Para a realização da dissertação, foram selecionadas duas questões da pesquisa "Opinião Pública - O Brasil, a América e o Mundo":

Opinião Pública

P15. O que você acha que o Brasil deveria fazer com relação a um país no qual os direitos humanos não são respeitados? (1. Deve romper relações diplomáticas com esse país; 2. Deve procurar que organismos, como a ONU, que critiquem esses países; 3 . Não deve se envolver em assuntos internos desse país; 4. NS; e 5. NR).

\footnotetext{
${ }^{5}$ Surveys sobre opinião pública da elite e da massa, realizada pela Chicago Council on Foreign Relations.
} 
P30. Caso o exército ou um grupo armado de algum país latinoamericano derrubasse um governo eleito democraticamente, você acredita que o Brasil deveria...? (1. Romper relações diplomáticas com o novo governo; 2. Condenar as atitudes tomadas de forma pública, mas sem romper relações diplomáticas; 3. Esperar a reação internacional e então agir; 4. Não fazer nada; 5. NS; e 6. NR)

Como Variáveis Independentes (Vls), quatro questões serão utilizadas para entender sua relação com as Variáveis Dependentes (VDs):

\begin{tabular}{|l|c|c|}
\hline \multicolumn{1}{|c|}{ Variável Dependente } & $\begin{array}{c}\text { Opinião } \\
\text { Pública }\end{array}$ & $\begin{array}{c}\text { Opinião } \\
\text { Elites }\end{array}$ \\
\hline 1.1 Sexo & S1 & 80 \\
\hline 1.2 Idade & S2 & 81 \\
\hline 1.3 Escolaridade & S3 & 82 \\
\hline 1.4 Escala política (ideológica) & S12 & 95 \\
\hline
\end{tabular}

Dessa forma, o presente trabalho é dividido em duas partes, sendo a primeira uma revisão do debate sobre Opinião Pública, tanto no meio internacional quanto no nacional e sua relação com a discussão sobre Política Externa. Na segunda parte e como base da discussão, é apresentada a proposta da criação de uma tipologia da Opinião Pública em relação à Política Externa Brasileira. 


\section{CAPÍTULO 1 - Opinião Pública , Opinião Elite e Política Externa}

\subsection{Pré - definição sobre Opinião Pública?}

O debate sobre Opinião Pública nasce com os antigos filósofos gregos e se perpetua até os dias atuais. Sua definição, de acordo com Bobbio (2004), pode ter duplo sentindo, ou seja, em relação a sua formação, no caso de não ser privada e surgir do debate público e, no seu objeto, como 'coisa pública'. Em relação à ideia de opinião, pode ser sempre discutido, pois muda com o tempo e permite discordância, expressando juízo de valor. E, completa, "a Opinião Pública não coincide com a verdade, precisamente por ser opinião, por ser doxa e não episteme, mas na medida em que se forma e fortalece no debate, expressa uma atitude racional, crítica e bem informada" (2004: 842).

A discussão de Opinião Pública é um fenômeno da era moderna, pressupõe uma sociedade distinta do Estado, livre e articulada, com centros onde permitam que opiniões, não individuais, sejam formadas. Ou seja, "um público de indivíduos associados, interessado em controlar a política do governo, mesmo eu não uma atividade política não desenvolva uma atividade política de imediato" (Bobbio, 2004: 843). Dessa forma, para Bobbio o conceito de Opinião Pública está diretamente ligado à formação do Estado moderno com o monopólio do poder, privando a sociedade de todo o caráter político. Assim, a Opinião Pública surgiu para combater a compreensão de segredo de Estado, para conquistar o máximo de 'publicidade' dos atos do governo.

Outro autor que discute a definição de Opinião Pública é o filósofo alemão, Immanuel Kant. Apesar de não usar o termo offentliche meinung 
(opinião pública) explicitamente, se remete ao uso da razão, ou o uso público da razão. Esse conceito aparece em uma pequena obra chamada "Resposta à pergunta: o que é Esclarecimento", escrito no final de $1783^{6}$. O conceito de Opinião Pública está diretamente ligado à origem política e se enquadraria no sistema da razão teórica como um conceito empírico, ou seja, as ações humanas devem ser regidas pela razão. Dessa forma, o conceito empírico de Opinião Pública é indispensável para alcançar uma teoria política racional.

Para Herbert Blumer (1971), a Opinião Pública deve ser entendida como um produto coletivo. Segundo ele, porém, "não constitui uma opinião unânime com a qual cada membro do público está de acordo, não sendo, também, forçadamente a opinião da maioria" (1971: 184). Por ser um produto coletivo e estar ligada a uma decisão, a Opinião Pública representa o público como o todo, ou seja, proporciona uma ação em conjunto, porém não está necessariamente com base num consenso e pode não chegar a ser unânime.

A seguir, será apresentado um breve levantamento histórico sobre a Opinião Pública, com o início do debate sobre o assunto, discutindo suas origens e principais debates até o século XIX.

\subsection{A história da Opinião Pública}

Os primeiros debates sobre Opinião Pública surgiram na antiguidade. Alguns exemplos podem ser citados, principalmente para apresentar que 0 tema já era discutido por filósofos clássicos, como Platão e Aristóteles. Segundo Platão (428/427 - 348/347 a.C.) , a Opinião Pública podia ser

\footnotetext{
${ }^{6}$ Essa obra é um dos primeiros trabalhos do autor no sentido de construir uma ética, tema que se torna sua principal preocupação depois da publicação de "Crítica da Razão Pública".
} 
considerada essencial para o bom funcionamento do governo e, assim, o governante não deveria ter preocupações com prováveis reivindicações, pois o povo era incapaz de ter qualquer tipo de compreensão do funcionamento do governo.

A doxa ${ }^{7}$ platônica representa o mais baixo nível de conhecimento, apontado como uma forma de semi-ignorância, com base em ambiguidades sendo consideradas reais pelo cidadão comum. Para Platão, de acordo com Muñoz-Alonso (1992:24) o ser público é o grande sofista, pois surge um vínculo entre opinião e povo desesperado. Geralmente deve-se desconfiar da massa, pois falta a certeza de que as pessoas poderiam realizar seus próprios interesses ou se esforçavam em direção à um Estado moralmente são. A opinião pública, acreditava, estaria diretamente ligada à ideia de sentimento popular.

Em contrapartida, para Aristóteles a opinião pública não pode ser considerada como um reflexo do sentimento popular, mas como equivalente aos valores, normas e gostos da civilização. Aristóteles vê sabedoria nas ideias e expressão dos cidadãos ao atuarem em público. Os debates entre seguidores destes argumentos, sejam eles platônicos ou aristotélicos, sobre o valor da opinião pública continuam até os dias de hoje, embora de forma um pouco diferente.

Vale ressaltar, pois para um pensador preocupado com a imagem do Príncipe e de como seu poder deve ser mantido, Maquiavel foi respeitoso com

\footnotetext{
${ }^{7}$ Palavra grega que significa crença comum ou opinião popular. Para maiores informações: ABBAGNANO, Nicola. Dicionário de Filosofia. São Paulo, Martins Fontes: 2007. p.294
} 
a Opinião Pública, mas apenas por considerá-la uma força política com potencial para trazer prejuízos ao príncipe e ao Estado. Ele não era um defensor da sabedoria da opinião pública como Aristóteles, pois não estava preocupado com a harmonia da comunidade ou o estado moral da política. De acordo com Maquiavel, havia um conflito na sociedade entre governante e governado. Essas duas partes estão sempre desconfiando uns dos outros, embora o príncipe tenha sempre o poder nas mãos. Para Maquiavel, a Opinião Pública era volátil, irracional e potencialmente explosiva (Glynn et al, 2004: 44)

1.3Os primeiros estudos sobre Opinião Pública - século XVII e XVIII

Seguindo a linha de Maquiavel, dois filósofos inglês do século XVII, Thomas Hobbes e John Locke, também demonstraram grande interesse na relação entre sociedade, Estado e o papel da Opinião Pública. Hobbes tinha uma visão negativa da natureza humana, acreditando que as pessoas viviam em constante competição, disputando propriedade, reputação e segurança pessoal. Em sua obra, "O Leviathan", ele descreve a vida humana como solitária, pobre, desagradável, brutal e curta. Em sua teoria do 'contrato social', a Opinião Pública era crucial para a formação do Estado. Porém, segundo o autor, um dos principais teóricos do absolutismo, a Opinião Pública deve ser condenável por introduzir no Estado a semente da anarquia e da corrupção.

John Locke foi o primeiro pensador a introduzir uma concepção mais avançada da discussão da Opinião Pública na política. Como pensador iluminista, defendeu, no século XVII, uma lei, com normas, da Opinião Pública, pois reconhece de maneira mais sistemática seu papel fundamental na política. Locke é um autor contratualista, como Hobbes, e também defendia a ideia de 
um pacto entre as pessoas e os líderes, para assim, governarem. Porém, tinha uma visão mais otimista da natureza humana.

Em relação a opinião popular, Locke foi um pouco cético e acreditava ferozmente na articulação da opinião pública como uma parte crítica da política. A Opinião Pública, de acordo com ele, de um lado tem sua base em fenômenos sociais e diz respeito à vida política/pública, e de outro é um fenômeno social, pois nasce em determinados contextos e, logo, não é estática.

Para Jean-Jacques Rousseau, filósofo do século XVIII, a Opinião Pública representa juízos morais, consentindo com a política e com os canais institucionais por meio dos quais são expressas e está diretamente ligada à ideia de vontade geral. Embora a discussão de Rousseau seja um pouco complexa e até confusa, ele argumenta que a Opinião Pública é uma agregação de opiniões individuais e uma força mais orgânica enraizada em valores e atitudes compartilhados.

Portanto, para Rousseau, os cidadãos pensam sobre si mesmos e suas necessidades, mas também são capazes de pensar sobre o bem geral da sociedade. Ao contrário de muitos filósofos anteriores a ele, partia do princípio que as pessoas eram difíceis de serem manipuladas. Essas pessoas, argumentou, são basicamente honestas e esperaram honestidade dos outros incluindo seus líderes (Glynn et al, 2004: 46). 
O filósofo alemão, Immanuel $\mathrm{Kant}^{8}$ apesar de não ter usado explicitamente o termo "Opinião Pública" (offentliche meinung), utiliza a ideia de uso da razão, diretamente ligada à origem política e se enquadraria no sistema da razão teórica como um conceito empírico, ou seja, as ações humanas devem ser regidas pela razão. Dessa forma, para ele o conceito empírico de Opinião Pública é indispensável para alcançar uma teoria política racional. Assim, de acordo com Bobbio (2004), Kant mostra a Opinião Pública como um fenômeno histórico, específico de sua época de esclarecimento, pertencendo à esfera da ação política. Porém, não se ilude ao reconhecer sua fragilidade, muitas vezes ameaçada pelo arbítrio e insiste no valor dos governantes que respeitam a liberdade de expressão.

Os autores federalistas James Madison, Alexandre Hamilton e John Jay, no século XVIII, acreditavam que as "paixões" do público por serem flutuantes, cometiam "erros e delírios" referentes à sua opinião pública. Na época, prevalecia a visão de mudanças frequentes nas preferências da Opinião Pública de forma rápida e arbitrária. Dessa forma, para os pensadores, a estabilidade da opinião pública não é confiável, fazendo, assim, sentido em limitar o poder e concentrar o processo de tomada de decisão com pessoas devidamente competentes e qualificadas.

Não devemos deixar a era da Revolução Francesa (1789 - 1799), sem mencionar o ministro das Finanças de Luís XVI, um homem chamado Jacques Necker, que muitos acreditam ter popularizado o termo "opinião pública".

\footnotetext{
${ }^{8}$ Immanuel Kant (1724 - 1804), publicou em 1783 um pequeno livro chamado "Resposta à Pergunta: o que é Esclarecimento?", onde aborda a questão do uso da razão e se torna um dos primeiros trabalhos no sentido de construir um ética, tema que se torna sua principal preocupação depois da publicação de "Crítica da Razão Pura".
} 
Necker reconheceu que, o discurso político e a natureza da política haviam mudado dramaticamente no século XVIII. Em um primeiro momento, a burguesia se reunia para discutir política através do diálogo interpessoal e através da imprensa. Na época, a opinião pública significou a opinião da classe média. Mesmo em uma monarquia, Necker reorganizou o quanto da estrutura institucional do Estado repousava sobre a benevolência da opinião pública. A maioria dos estrangeiros, observou,

have a difficulty in forming a just idea of the authority exercised in France by public opinion; they have difficulty in understanding the nature of an invisible power which, without a bodyguard, and without an army gives laws to the city, to the court, and even to the palaces of kings. (apud Glynn, 2004: 47)

A partir do século XIX, uma variedade de filósofos políticos abordou difíceis questões a cerca da natureza da opinião pública e serão apresentados a seguir.

\subsection{Teorias sobre Opinião Pública no século XIX}

Jeremy Bentham foi o primeiro utilitarista ${ }^{9}$ a ter uma extensa produção sobre Opinião Pública, e a tratar minuciosamente do assunto. Sublinhou a importância da opinião pública como meio de controle social, discutiu sua relação com a legislação e foi um dos primeiros a examinar o papel desempenhado pela imprensa na sua formação. a opinião pública, afirmava, era necessariamente parte integrante de qualquer teoria democrática do

\footnotetext{
${ }^{9}$ Teoria Utilitarista é uma doutrina ética defendida, principalmente, por Jeremy Bentham e John Stuart Mill, que partem do princípio que as ações são boas quando tendem a promover a felicidade. A frase "Agir sempre de forma a produzir a maior quantidade de bem-estar" - Princípio do Bem-Estar. Para maiores informações: http://plato.stanford.edu/entries/utilitarianism-history/
} 
Estado. O problema fundamental da opinião pública era "salientar a retidão das decisões por ela tomadas". Bentham, John Stuart Mill, e outros filósofos ingleses, acreditavam na democracia, mas enfatizavam a importância da opinião da maioria. De acordo com esses autores, as leis só são necessárias onde a 'lei da opinião' não funciona de forma eficaz.

Com uma visão similar, onde considera a Opinião Pública como uma força de controle social, Alexis de Tocqueville, em seu livro A Democracia na América, escreve sobre a igualdade política e sua relação com a Opinião da Massa. Ele observou que, em sociedades onde existe muita desigualdade, a opinião pública não é vista com grande importância. Isso ocorre porque as pessoas menos favorecidas economicamente reconhecem maior grau de instrução nas pessoas mais economicamente favorecidas são mais instruídas e, portanto, têm opiniões mais embasadas. No entanto, os cidadãos de maior igualdade se veem como tão capazes quanto seus amigos, colegas de trabalho e vizinhos. Essa percepção é particularmente relevante numa época de comunicação de massa, onde é possível para todas as pessoas recolher grandes quantidades de informações sobre os assuntos públicos sobre os quais eles podem basear suas opiniões.

Enquanto Tocqueville escrevia sobre política americana, Karl Marx também pensava e debatia sobre a vida política e social, porém de um ponto de vista totalmente diferente. Para Marx, um homem completamente insatisfeito com o status quo e acreditando na democracia (como outras formas de governo) foi sujeito à corrupção por parte das forças do capitalismo. Mas é importante mencionar, pelo menos, uma das ideias fundamentais de Marx 
sobre a opinião pública. Ele não costumava usar a expressão "opinião pública", em parte porque a frase não era comumente utilizada no pensamento filosófico alemão até o final do século.

Em A Ideologia Alemã (2002), Marx e Engels observaram no cidadão comum uma tendência a imitar a opinião dos pertencentes à classe dominante - pessoas com grande riqueza e poder. Para eles, as pessoas aceitam a sabedoria comum às atitudes e os valores da elite dominante, mesmo que tais atitudes, muitas vezes, não estejam de acordo com seus próprios interesses. Como resultado, a classe trabalhadora não exercia muito poder político: era incapaz de perceber os seus interesses, porque seus membros passaram a acreditar que a classe dominante sabe o que é melhor.

No final do século XIX, um estadista britânico chamado James Bryce viajou aos Estados Unidos para observar o cenário político. Em sua obra The American Commonwealth (1988), Bryce examinou a opinião pública na tentativa de entender como sua concepção se encaixava nas instituições americanas. Ele estava interessado em como a expressão e medição da opinião pública estariam relacionadas com a atividade do partido, das legislaturas e dos meios de comunicação durante este período. Ele é frequentemente citado como uma das primeiras teorias "modernas" da opinião pública. Em vez de especular sobre a natureza da opinião pública, ele olhou para suas manifestações na cultura política.

Em sua obra, Bryce deu ênfase, como ninguém antes tinha feito, à importância dos jornais nas comunicações de opinião pública. Para ele, os meios de comunicação eram incrivelmente poderosos e ocupavam um lugar 
entre as outras instituições (Congresso, os tribunais) como um modelador de opinião pública. Bryce destacou o papel da comunicação do sentimento popular. No entanto, deixa claro que ninguém - incluído os políticos - pode depender inteiramente de jornais para obter uma visão abrangente da opinião pública.

De acordo com ele, a opinião pública pode ser definida como "qualquer ponto de vista, ou conjunto de pontos de vista aceitos por uma aparente maioria dos cidadãos, ou seja, muitas vezes identificada com a 'tirania da maioria'”(SILVEIRINHA, 2004: 424), assim, prevaleceria a opinião da 'maioria silenciosa' e não dos indivíduos e o predomínio da diversidade. Bryce, por exemplo, reforça a presença dos meios de comunicação de massa como poderosos e "os jornais como os órgãos mais importantes e mesmo cruciais, pois refletem a opinião pública" (SILVEIRINHA, 2004, p. 424).

Outro teórico dos assuntos públicos e da relação entre jornais e discussão interpessoal foi o sociólogo francês Gabriel Tarde, escrevendo sobre a opinião pública nas primeiras décadas do século $X X$. Ele observou em seu ensaio Opinion and Conversation, "conversation at all times, and the press, which at presente is the principal source of conversation, are the major factors in opinion" (apud GLYN et al, 2004:53) . Na verdade, Tarde apresenta um modelo de formação de opinião unidirecional podendo ser representado pela relação: Mídia - Conversa - Opinião - Ação. Esse é um modelo a ser usado para pensar sobre o papel de jornais na ação política. Gabriel Tarde acreditava firmemente que os jornais seriam como um trampolim nacional para discussão política. 
Gabriel Tarde escreveu uma variedade de textos onde abordou as questões fundamentais sobre a opinião pública - seu significado, como opera, e qual a sua relação com as instituições políticas e culturais. De acordo com ele "a opinião é para o público moderno o que a alma é para o corpo" (TARDE, 1986: 79 apud SILVEIRINHA, 2004: 425). "A opinião é definida como um grupo de juízos, momentâneo e mais ou menos lógico, que responde a problemas reais e que se encontra reproduzida em numerosas pessoas do mesmo país, do mesmo tempo e da mesma sociedade" (SILVEIRINHA, 2004, p. 426).

O conceito de Opinião Pública está diretamente ligado à discussão de esfera pública, defende o filósofo Jürgen Habermas (1971), pois um sujeito só faz parte de uma esfera pública enquanto portador de uma opinião. O conceito de opinião pública para ele tem como base a ideia da racionalização ser inerente à condição humana, ou seja, possuem em si a capacidade de racionalizar. Assim, para Habermas(1971),

A opinião Pública refere-se às atitudes de pessoas diante de uma questão quando elas são membros do mesmo grupo social. (...) De início, o público enquanto sujeito da opinião pública, foi identificado com a massa, e depois com o grupo, entendido como o substrato sócio-psicológico de um processo de comunicação e interação entre dois ou mais indivíduos. (1971: 192)

\subsection{O debate contemporâneo sobre Opinião Pública}

Recentemente, as pesquisas realizadas apresentam duas visões diferentes: de um lado, uma visão mais cética, se encaixando no modelo 
pluralista, partindo do princípio de uma diferença entre um público atento numericamente pequeno e um público de massa muito maior. E do outro, uma visão otimista, que defende a ideia de uma Opinião Pública coerente, razoavelmente informada e a influência depende do contexto e do tema discutido. A primeira possuiria conhecimento suficiente para segurar visualizações coerentes sobre assuntos externos; e o segundo grupo seria mal informado, instável e propenso a mudanças irracionais de opinião.

Nesse modelo pluralista, Gabriel Almond seria o grande precursor dessa linha, além de nomes como Walter Lippman, Ole Hosti e teóricos realistas e neo-realistas, como Hans Morgenthau e John Mearsheimer. Para eles, a opinião pública da minoria, além de ser irracional e instável, é volátil, incoerente e com baixa ou nenhuma influência, principalmente em questões de política externa. Para os pensadores que defendem um viés positivo da Opinião Pública, principalmente em regimes democráticos estão nomes como Robert Shapiro, Benjamin Page, Lawrence Jacobs, Eugene Wittkopf, entre outros.

O sociólogo francês Pierre Bourdieu ${ }^{10}$, em 1979 decretou veemente: "a opinião pública não existe" (idem). Tal crítica está diretamente ligada às sondagens de opinião pública pois servem aos interesses das elites políticas e jornalísticas sendo sua mais importante função "impor a ilusão de que a opinião pública existe, e que é simplesmente a soma de um número de opiniões individuais" (ibidem). De acordo com sua análise, a opinião pública da forma como é apresentada pela mídia de massas é "um puro e simples artefato cuja função é ocular o fato de que o estado da opinião em qualquer momento é

\footnotetext{
${ }^{10}$ Disponível em: http://evoluireducacional.com.br/wp-content/uploads/2012/08/21979592-BourdieuA-opiniao-publica-nao-existe.pdf
} 
resultado de um sistema de forças, tensões, e de que não há nada mais inadequado do que porcentagens para representar tal estado de opinião" (ibidem).

Para Bourdieu (1979), as pesquisas de Opinião Pública são sustentadas a partir de falsas suposições, sendo a primeira a de que todos cidadãos são intelectual e politicamente competentes para conseguirem entender e interpretar as questões, tal como pesquisadores e jornalistas e, além disso, todos têm uma opinião sobre os temas de interesse dos políticos e da mídia.

Desde o início das sondagens de opinião pública, os pesquisadores presumiam que os entrevistados, com frequência, expressariam uma opinião acerca de um determinado tema sobre o qual não tinham conhecimento, e o faziam para que não parecessem ignorantes e, também, para satisfazerem a demanda social de que tenham opinião (Bishop, 2005). Porém, é praticamente impossível descobrir se cada entrevistado realmente tem conhecimento sobre o assunto questionado, principalmente pelo fato de que as sondagens de opinião são realizadas em ampla escala, o que demandaria mais tempo e recursos. Assim, naturalmente, foi acontecendo de tornar-se padrão ignorar ou subestimar o problema da Opinão Pública. No entanto, Philip Converse (1964) demonstrou que havia uma fonte preocupante de erro nas pesquisas de Opinião Pública, as 'não-atitudes'; que pode ser entendidas como opiniões artificiais e instáveis, vazias de conteúdo, bem como com ausência de atitude real. Para ele, antes de qualquer questionamento sobre determinado assunto, o ideal seria saber se as pessoas entrevistadas realmente possuem algum 
conhecimento sobre o assunto ou, no mínimo pensaram a respeito (Converse, 1964).

Para Converse (1964), a Opinião Pública está relacionada a um sistema de crenças individuais, implicando em reflexões sobre como a massa apreendem o mundo, como os líderes o fazem e qual a influência exercida de um sobre o outro. Segundo ele, "we define a belief system as a configuration of ideas and attitudes in which the elements are bound together by some form of constraint or functional interdependence" (1964: 207). Dessa forma, os sistemas de crenças implicam em peças de ideias que estão interconectadas, com contornos de influência mútua.

Para explicar a relação da Opinião Pública e da Elite sobre Política Externa, segundo o esquema proposto por Powlick \& Katz (1998), a Opinião Pública é largamente passiva, que exerce um julgamento retrospectivo em resposta a controvérsias entre elites, as quais são mediadas pela mídia. Os autores fazem uma associação entre as percepções dos cidadãos às das elites políticas, partindo do argumento que as atitudes do público têm um problema em sua estrutura ideológica, enquanto às dos líderes seriam marcadas por maior coerência, (Converse, 1964). Com isso, Powlick \& Katz (1998) criaram duas categorias de comportamento: "bottom-up”, onde os líderes seguem as massas, e "top-down", quando as massas seguem os líderes. Outras pesquisas, como Brewer et al (2004), também contrariam os argumentos de Converse, e defendem que as elites de política exterior, assim como as massas, utilizariam atalhos de informação, com base em teorias gerias, 
inclusive, não apontam diferenças estruturais sobre como essas elites formam seus julgamentos a agenda externa do Estado.

O autor Risse-Kappen (1991) apontou problemas nas duas visões de Powlick \& Katz, a "top-down" e "bottom-up", destacando que ambas tratam elite e massa como atores unitários. Para ele, é necessário um estudo mais amplo, principalmente entre democracias liberais, para perceber as diferenças entre as estruturas domésticas de cada país e suas eventuais consequências sobre o impacto da Opinião Pública sobre a Política Externa. Assim,

(...) under given international conditions and despite relatively similar public attitudes across countries, variances in the interaction between the general public and elites in the foreign policy-making process can be explained by differences in domestic structures. (1991: 511)

O sociólogo francês Patrick Champagne, em seu livro Formas a Opinião - o novo jogo político (1998), propõe discutir as pesquisas de Opinião Pública. Se de um lado Pierre Bourdieu., nos anos 70 negava a existência da Opinião Pública, Champagne considera que atualmente existem diferentes modos de existência, de acordo com o quadro de mudanças do contexto histórico no que se refere ao investimento nos chamados institutos de sondagem. (Champagne, 1998: 32). Segundo ele, não existe verdadeira Opinião Pública, porém há uma definição social mutável, referindo-se ao campo social dos agentes com interesse em invocá-la ou manipulá-la. Essa Opinião Pública é interferida pela mídia, que nem sempre "está de acordo com o bem público e o interesse geral" (1998:79). 
O jornalista Walter Lippmann parte da premissa de que a Opinião Pública, em um determinado sentido é uma ilusão, pois "fica claro que se torna impossível às pessoas chegarem a um sentido comum das ocorrências e dos fatos e a um propósito unificado" (2010:14) Dessa forma, completa, que a Opinião Pública não emerge das pessoas naturalmente, "é um processo de animação social através do qual estes personagens interessados no controle social se envolvem" (idem). Lippmann escrevia logo após a I Guerra Mundial, desencantado com o que considerava o 'injusto' Tratado de Versalhes e com a Liga das Nações, além do desagrado por Woodrow Wilson, pois o culpado, para ele, era o público americano, pois a realidade internacional era muito diferente das imagens que os cidadãos montavam em suas cabeças, e por isso conduzia a população a erros e contradições.

(...) a ação política deveria ser deixada a critério dos poucos bem-informados homens de ação. (...) O público é visto como um fantasma, pois a pessoa comum não consegue ter opinião de qualidade sobre assuntos públicos que a torne habilitada rotineiramente a exercer este papel. Não há método algum, nem a ciência nem a imprensa, capaz de fornecer aos seres humanos um guia independente para conduzir os assuntos humanos. (2010: 15)

Mantendo a mesma linha de raciocínio de que as atitudes do púbico em geral a respeito da política externa eram consideradas opiniões voláteis, emocionais e incoerentes, Gabriel Almond (1960) realizou um estudo analisando a Opinião Pública, que ele chamava de massa e sua relação com a política externa. $O$ autor se baseou nas pesquisas realizadas pelo Instituto 
Gallup, entre os anos 1935 e 1949 e encontrou uma grande variação ao analisar as respostas. Ao questionar qual seria o principal problema dos Estados Unidos para cada ano percebeu que a resposta relacionada a política externa variava numa média de 20 pontos percentuais, ou seja, em 1935, 11\% das respostas e, em 1941, durante a Segunda Guerra Mundial, as respostas saltaram para $41 \%$.

A partir disso, Almond identificou três problemas na Opinião Pública americana: $1^{\circ}$ ) mostrava-se mal informada sobre assuntos relacionados à política externa; $2^{\circ}$ ) apresentava mal grau de volatilidade nas opiniões no decorrer dos anos $\mathrm{e}, 3^{\circ}$ ) a opinião dos indivíduos apresentava uma tendência a mudar em momentos de crise. A explicação para esse comportamento é que o público está mais preocupado com assuntos que influenciam diretamente a sua vida. Esse argumento pode ser encontrado em teóricos realistas das relações internacionais, que partem da premissa, como já apresentado, que assuntos de política externa são considerados distantes do cotidiano da população em geral.

Dessa forma, Almond argumenta que a política externa exige um alto grau de informação e se encontra longe da realidade das pessoas, assim, a causa do baixo interesse seria a complexidade do processo. Por muitos anos, suas conclusões não foram questionadas, principalmente pelo fato de que muitos estudos indicavam a grande volatilidade das opiniões da massa, ou seja, da Opinião Pública. 
Ole Hosti (1992) parte do chamado "consenso de Almond-Lippmann ${ }^{11 "}$ para os debates teóricos sobre o tema, afirmando que a Opinião Pública é flutuante, não há fundamentos em um raciocínio abstrato e, como consequência, incoerente e indiferente à política externa, que respondem apenas a ameaças imediatas, motivo pelo qual não teria importância alguma na tomada de decisão. Porém, apesar das poucas informações, as atitudes do público sobre as relações exteriores seriam coerentes, ou seja, "low information and an ambiguous foreign policy environment are actually likely to motivate"(1992: 448). Seguindo o mesmo raciocínio, para Hurwitz \& Peffley “ (...) paucity of information does not impede structure and consistency; on the contrary, it motivates the development and employment of structure" (1987: 1.114)

Nesse sentido, pode-se ressaltar que, de fato, a opinião pública em assuntos de política externa contém algumas peculiaridades: há uma centralização na tomada de decisão a qual, no caso do Brasil, é de responsabilidade do Ministério das Relações Internacionais (MRE/ Itamaraty), sendo costumeiramente alvo de menos disputas por grupos de interesse, apresentando assim uma tendência a gerar menos disputas político-partidárias, porém, é este cenário o MRE/Itamaraty ser torna especialmente suscetível à manipulação das mídias.

Porém, Page e Shapiro (1992) contestaram as argumentações de Almond, apesar de reconhecerem que, em se tratando de assuntos

\footnotetext{
${ }^{11} \mathrm{O}$ "Consenso Almond-Lippmann" surge logo após a II Guerra Mundial, onde afirmam que a Opinião Pública é volátil e irracional, portanto, se torna duvidosa, principalmente em assuntos de política externa. Além disso, acreditavam que era desprovida de interesse e suscetíveis a manipulação e por esse motivo não deveria ser estudada. Esse 'consenso' foi muito influente nas décadas de 1950 e 1960, porém se tornou enfraquecida com o fim da Guerra do Vietnã.
} 
internacionais, algumas variações podem ocorrer, principalmente em momentos de acontecimentos mundiais inesperados, como as guerras. E nesse ponto os autores não se distanciam muito da teoria de Almond, pois concordam que os efeitos de situações de crise que influenciavam nas opiniões do público e provocando variações nas respostas dos indivíduos. Mas, os autores chamam atenção para o fato de que a opinião pública não é apenas o resultado de manipulações emocionais, ela apresenta uma racionalidade que se diferencia da estabilidade absoluta e, por ser pública, essa opinião deve se remodelar sempre que houver uma alteração transitória ou perene na composição das relações sociais.

A partir de resultados empíricos, Page e Shapiro concluem que a opinião pública é racional e coerente. Ao analisar opiniões do público norte-americano sobre temas públicos encontraram altos índices de consistência e que aumenta à medida que os temas em discussão pública se tornam mais salientes. Em The Rational Public, os autores declaram que as maiores inconsistências na opinião pública foram encontradas nas opiniões formuladas sobre a política externa norte-americana. Segundo os autores, a opinião pública apresenta características descritíveis e, portanto, sua composição pode ser analisada teoricamente e também servir de ponto de partida para os agentes públicos tomares decisões.

Na primeira edição da revista Public Opinion Quarterly (1937), Floyd Allport analisou a literatura especializada na época em busca de entender os desentendimentos a respeito do conceito de Opinião Pública. Foyle chamou a atenção para as ilusões e soluções irrefletidas, tais como: 1) a personificação 
da opinião pública; 2) a personificação do público; 3) a ilusão do grupo; 4) a ilusão do uso parcial do termo público; 5) o que ele chama ficção de uma entidade ideativa; 6) a teoria emergente; 7) a teoria eulogística; 8) a ilusão jornalística. Segundo o autor, Opinião Pública "is thought of as some kind of being which dwells in or tyabove the group, and there express its view upon various issues as they arise" (1937:01)

Em um texto publicado em 1997, Foyle argumenta que as crenças das elites (principalmente políticas, como presidente e líderes) seriam uma variável intermediária entre a Opinião Pública e a Política Externa, classificando-as em duas dimensões: crenças normativas e crenças práticas. A primeira está diretamente ligada à ideia de que há um desejo onde a Opinião Pública influenciaria na decisão em política externa; na segunda, o apoio do público à política é condição necessária para conquistar o fim desejado. Assim, de acordo com Ferraz (2014), Foyle

(...) defende a visão de que crenças e atitudes do tomador de decisão influenciam sua reação à opinião pública, e variáveis individuais concernentes ao mesmo devem, portanto, ser levadas em conta na análise do vínculo entre o público e as políticas (2014: 08).

\subsection{Opinião Pública X Opinião de Elite em Política Externa}

O debate acerca da participação de atores sociais vem de uma longa tradição oriunda dos filósofos gregos clássicos que analisa seus efeitos no funcionamento das instituições democráticas. A partir do século XVIII, grandes discussões surgem em relação aos efeitos da participação política dos 
cidadãos no funcionamento das instituições. A identificação do grau de participação e influência dos grupos sociais nos processos políticos é um ponto importante no debate da literatura democrática. A sociedade democrática é caracterizada pela existência de uma minoria provida de qualidades consideradas superiores ao restante da população e que, vale ressaltar, detém o poder econômico e político. E é a partir desse grupo minoritário que surge a Teoria das Elites ${ }^{12}$ :

(...) se entende a teoria segundo a qual, em toda a sociedade, existe, sempre e apenas, uma minoria que, por várias formas, é detentora do poder, em contraposição a uma maioria que dele está privada. Uma vez que, entre todas as formas de poder (entre aquelas que, socialmente ou estrategicamente, são mais importantes estão o poder econômico, o poder ideológico e o poder político), a teoria das Elites nasceu e se desenvolveu por uma especial relação com o estudo das Elites políticas, ela pode ser redefinida como a teoria segundo a qual, em cada sociedade, o poder político pertence sempre a um restrito círculo de pessoas: o poder de tomar e de impor decisões válidas para todos os membros do grupo, mesmo que tenha de recorrer à força, em última instância. (Bobbio, 2005: 385)

As elites, como grupo unificado, controlam as principais hierarquias nas instituições sociais, como Estado, Empresas, Forças Armadas, entre outros, tomam decisões que afetam a Nação como um todo. Pois, é a partir de sua posição privilegiada ocupada nas instituições, garante o poder no processo decisório. Em uma sociedade democrática, há uma crença onde o povo

\footnotetext{
${ }^{12}$ O termo Elite foi utilizado pela primeira vez pelo cientista político italiano Pareto, em sua obra de 1902 - Systèmes Socialiste. Porém, vale ressaltar que a formulação de um grupo minoritário detentora do poder foi de Gaetano Mosca, em Elementi di scienzia politica - 1896.
} 
influencia nas decisões, e as elites utilizam os veículos de comunicação para transmitir suas ideias ao restante da população.

A dificuldade da massa para construir um quadro com base em fatos e eventos reais de forma coerente e organizada, é explicada, segundo Schumpeter (1961), pela capacidade de reduzir e discriminar fatos, principalmente aqueles que não os atingem diretamente. Para ele, "o senso de responsabilidade reduzido e a ausência de vontade efetiva, por outro lado, explicam a ignorância do cidadão comum: e a falta de bom senso em assuntos de política interna e externa" (1961: 318).

Uma proposta de distanciar a visão elitista da dicotomia elite-massa (Schumpeter, 1961; Mills, 1972), é realizada por Kaplan e Lasswell (1979), ao atribuírem gradações distintas de participação. Os autores identificaram três grupos na sociedade: elite, massa e intermediário. O primeiro grupo, a elite, é composto por aqueles que têm maior poder na sociedade e maior grau de organização; o segundo, a massa, é considerada desorganizada, constituída por aqueles que possuem menor poder na sociedade. E, de acordo com a nova proposta de Kaplan e Lasswell (1979), o novo grupo seria o intermediário, composto por aqueles que têm um poder menor que da elite, porém superior ao da massa.

Segundo Sartori (1992) e Deutsch (1968), cabe aos líderes o papel central na formação da opinião e na sua transmissão para a sociedade. Para Deutsch (1968), a formação da Opinião Pública pode ser comparada à uma cascata, nesse caso, com cinco níveis, sendo que as elites econômicas e sociais estariam na parte mais elevada; seguidas das elites políticas e 
governamentais, no terceiro nível as redes de comunicação de massa, que são os responsáveis na transmissão e difusão das mensagens oriundas dos outros níveis; o quarto seria composto pelos "líderes de opinião", que representam um pequena parcela da população que se interessam por política e estão atentos às mensagens transmitidas. E, ocupando o último e quinto nível, encontra-se a massa.

Nesse modelo, cada nível funcionaria como um filtro de informação para os demais, e a diferença entre o primeiro e o último nível seria o grau de estruturação e sofisticação das opiniões e percepções. Deustch (1968) também mostra que esses níveis não são monolíticos, e no seu interior estão localizados os interesses discordantes. Para Sartori (1992), que segue o mesmo raciocínio de Deustch, os líderes de opinião desempenham um importante papel nesse processo, pois a comunicação de massa é um veículo impessoal que não substitui o contato pessoal. E complementa, as pessoas escutam a um determinado líder local, podendo suas mensagens serem reforçadas, bloqueadas ou distorcidas (Sartori, 1992: 156).

Os estratos intermediários que exercem pressões nas elites são o foco da visão pluralista ${ }^{13}$, que parte do pressuposto que nem todos os cidadãos participam de forma ativa nos processos de tomada de decisão. Um

\footnotetext{
13 “ Na linguagem política chama-se assim a concepção que propõe como modelo a sociedade composta de vários grupos ou centros de poder, mesmo que em conflito entre si, aos quais é atribuída a função de limitar, controlar e contrastar, até o ponto de o eliminar, o centro de poder dominante, historicamente identificado como Estado. Como tal, o Pluralismo é uma das correntes do pensamento político que sempre se opuseram e continuam a opor-se à tendência de concentração e unificação do poder, própria da formação do Estado moderno.(...) A luta que o Pluralismo trava tem sempre duas frentes: uma contra a concentração de todo o poder no Estado, outra contra o atomismo. É uma luta travada em nome da concepção de uma sociedade articulada em grupos de poder que se situem, ao mesmo tempo, abaixo do Estado e acima dos indivíduos, e como tais, constituam uma garantia do indivíduo contra o poder excessivo do Estado, por um lado e, por outro, a garantia do Estado contra a fragmentação individualista". (Bobbio, 2004: 928)
} 
representante do pensamento pluralista é Robert Dahl (1977), mostrando que apenas uma parcela restrita dos cidadãos teria uma presença política mais evidente, com interesse pelas grandes decisões, com participação nas discussões e nas ações.

Essa parcela apresentada por Dahl (1977) seria o estrato político, formado pelo restante da população, ou seja, a maioria. Para esse pequeno grupo, a política seria uma referencia bastante forte, com suas escolhas e estratégias calculadas, com base na racionalidade, coerência e consistência. Para o segundo grupo, suas escolhas seriam o resultado da inércia, do hábito, da lealdade, das emoções e impulsos, e suas orientações seriam desconexas e não-ideológicas; a política seria algo distante. Porém, isso não significa que a maioria dos indivíduos não exerça algum tipo de influência, ainda que indireta, ou que não tenha seus interesses garantidos. Uma influência, mesmo que indireta, ocorreria na competição entre os líderes durante o período eleitoral, buscando o apoio do eleitor (Holzhacker, 2006: 34)

Assim, percebe-se nessas análises uma predominância de uma visão pessimista da capacidade da massa em atuar nos processos políticos. Por causa das emoções e das paixões, as decisões e opiniões racionais em assuntos políticos ficam prejudicadas. Isentos dos males que afligem as massas - paixões, irracionalidade, emoções e a falta de perspectiva dos fatores reais - as elites seriam a fonte de informação e os decision makers na sociedade.

As pesquisas de opinião trouxeram novos pressupostos para a discussão da relação entre massa e elite, levando a reformulações das visões 
tradicionalistas, principalmente, em relação ao comportamento da massa. De forma mais ampla, pesquisas sobre o assunto buscavam comparar o grau de conhecimento, interesse e quais eram as diferenças entre as atitudes das elites e das massas sobre as questões políticas. Os estudos nessa área concentramse na busca de identificar os fatores que poderiam influenciar no comportamento político dos indivíduos. Alguns autores, como Lazarsfeld, Berelson e Caudet $^{14}$ (1944), acreditavam que variáveis como religião, posição social e local da residência poderiam explicar as posições políticas dos indivíduos.

Um dos artigos mais influentes que analisa os fatores que influenciam o comportamento dos indivíduos é de Philip Converse, The Nature of Belief Systems in Mass Public, publicado em 1964. O trabalho de Converse não apenas inovou metodologicamente, ao adotar pesquisas consecutivas e com o mesmo grupo de entrevistados, onde analisou a opinião de eleitores sobre política pública em três momentos seguidos, 1956 - 1958 - 1960, utilizando a técnica de pesquisa denominada "Painel", que consiste na repetição das entrevistas como os mesmos indivíduos, em momentos diferentes. Para Converse (1964), as atitudes e opiniões, uma vez formadas, tendem a ser estáveis no tempo e inter-relacionam-se com outras que sejam logicamente consistentes com elas (1964: 208).

A discussão recente sobre o comportamento da massa, partindo de várias perspectivas teóricas, indica um crescente otimismo, através das

14 Em estudos realizados por esses autores, em 1944, mostraram que características demográficas influenciavam na escolha eleitoral. Outro aspecto importante apresentado por eles foi o processo de formação da opinião e o papel desempenhado pelo líder local na transmissão da informação durante a campanha eleitoral. 
mudanças no público nos últimos anos, de acordo com autores como Zaller (1992), Page \& Shapiro (1992), Miller; Shanks (1996), Erikson \& Tedin (2001). A evolução nas pesquisas a respeito do comportamento sugere que as diferenças de opiniões entre massa e elite não são tão evidentes quanto pareciam indicar as pesquisas realizadas entre as décadas de 1940 e 1960.

Tanto nos Estados Unidos quanto na Europa, é comum o emprego de sondagens de opinião para realizar análises do comportamento da Massa (ou do Público) e das Elites a respeito da agenda externa do país. No caso dos EUA, os institutos Gallup ${ }^{15}$ e o Chicago Council Foreign ${ }^{16}$ Relations, realizam periodicamente pesquisas para mensurar a base interna de apoio do país e a atitude da população em relação à política externa. Na Europa, as pesquisas realizadas pela Comunidade Europeia, desde a década de 1970, avaliam o grau de apoio dos europeus à integração na região.

\subsection{Opinião Pública e Política Externa Brasileira}

Em relação ao Brasil, as pesquisas de opinião pública tem se tornado, cada vez mais, uma importante ferramenta analítica, inclusive em temas relacionados à política externa. O Núcleo de Relações Internacionais da Universidade de São Paulo (NUPRI) têm importantes trabalhos que abordam as orientações e estratégias dos diversos setores da sociedade a respeito da política externa brasileira, tanto na visão da elite quanto da população em geral. Pode-se destacar a pesquisa "As percepções da elite e opinião pública sobre a política externa brasileira" (1998-2000). Outro importante trabalho realizado sobre o tema é de Denilde Oliveira Holzhacker, "Atitudes e

\footnotetext{
${ }^{15}$ Para maiores informações, ver: http://www.gallup.com/home.aspx

${ }^{16}$ Para maiores informações, ver: $\underline{\text { http://www.thechicagocouncil.org/ }}$
} 
percepções das elites e da população sobre a política externa brasileira nos anos 90" (tese de doutorado) e "As atitudes e opiniões da população a respeito das relações externas do Brasil" (dissertação de mestrado).

Um trabalho de grande importância e que se tornou referência para entender a agenda do Brasil no sistema internacional foi realizado por Amaury de Souza (2008), e apresenta o resultado de duas pesquisas de opinião, a primeira em 2001 e a segunda em 2008 com um determinado grupo de pessoas de diversos segmentos ${ }^{17}$, que integram a "comunidade brasileira de política externa $^{18 ”}$ (2008: 02). Entre as várias questões apresentadas pelo autor, uma merece destaque e está diretamente ligada à presente pesquisa, aquela que aborda o interesse da opinião pública pela politica externa. Após as entrevistas, o autor apresenta os seguintes dados:

\section{$\underline{\text { Interesse da Opinião Pública pela Política Externa }{ }^{19} \text { (Percentagem) }}$}

\begin{tabular}{|l|r|r|}
\cline { 2 - 3 } \multicolumn{1}{c|}{} & 2001 & 2008 \\
\hline Muito Interesse & 11 & 4 \\
\hline Pouco Interesse & 76 & 78 \\
\hline Nenhum Interesse & 13 & 18 \\
\hline
\end{tabular}

Fonte: SOUZA (2008)

\footnotetext{
${ }^{17}$ Segmentos: Poder Executivo, Congresso Nacional, Líderes Empresariais, Empresários, Acadêmicos e Jornalistas, Conselheiros e Consultores do Centro Brasileiro de Relações Internacionais.

${ }^{18}$ De acordo com Souza (2008), essa expressão designa "o universo constituído por pessoas que participam do processo decisório e/ou contribuem de maneira relevante para a formação da opinião no tocante das relações internacionais do país" (2008: 02).

${ }^{19}$ Tabela criada pela autora da dissertação.
} 


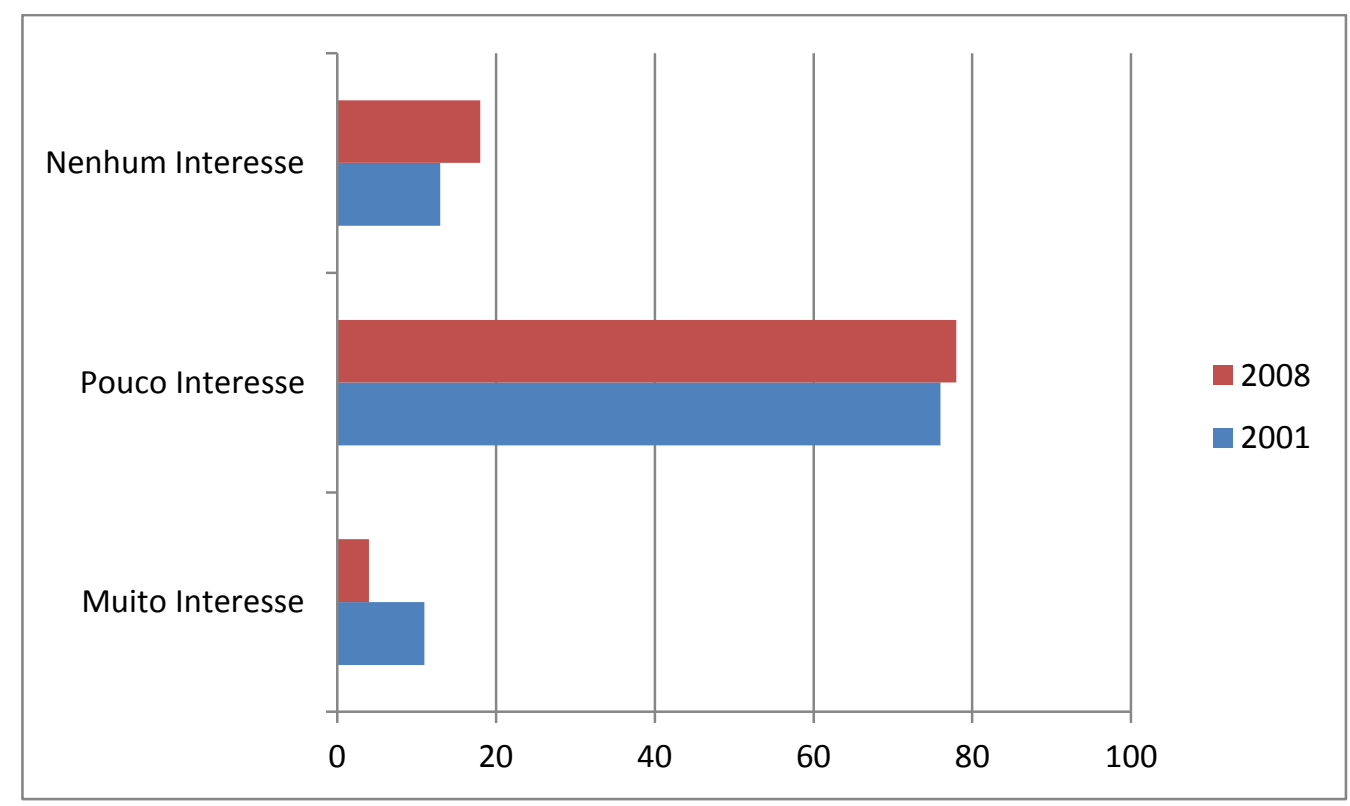

Fonte: Souza $(2009-$ p.128)

A principal hipótese, segundo o autor, é que o público tem baixos níveis de informações, inclusive de interesse sobre assuntos relacionados à agenda de relações internacionais e, assim, tende a ter uma reação de maneira mais emocional às oscilações da política externa. Para Souza:

(...) uma concepção mais atual enfatiza a interação entre líderes e o público na formação da política externa, especialmente pela manipulação de questões externas para angariar apoio no cenário doméstico. (2009:127)

Porém, o que os dados apresentam é que a opinião pública continua a ter pouco interesse pelo assunto, sendo em $2001,76 \%$ e, no ano de 2008 , apresentando um aumento de $2 \%$, indo para 78\%. E, apenas 4\%, em 2001 e 11\% em 2008 acreditam que há muito interesse da opinião pública em política externa. A principal justificativa para isso é que, historicamente, às decisões 
sobre os rumos da PEB estiveram tradicionalmente concentradas na diplomacia, ou seja, no Ministério das Relações Exteriores (MRE/Itamaraty). Fato recente e merece destaque são as mudanças que vêm ocorrendo, como a ideia do Congresso ou organizações exercerem influência sobre as relações internacionais do Brasil.

Vale notoriedade a pesquisa "Brasil, as Américas e o Mundo: Opinião Pública e Política Externa", sob coordenação geral do projeto Las Américas y el Mundo, realizada pelo Centro de Investigación y Decencia Económicas - CIDE (México). Esse trabalho faz parte de uma parceria acadêmica que inclui pesquisadores de vários países da América Latina: Argentina, Brasil, Chile, Colômbia, Guatemala, México e Peru. No caso do Brasil, a coordenação foi feita pela profa. Dra. Maria Hermínia Tavares de Almeida, no Instituto de Relações Internacionais, da Universidade de São Paulo (IRI/USP).

Esse projeto internacional buscou compreender as percepções e atitudes do público e das elites sobre os temas internacionais, captando sua reação às mudanças internacionais e seus impactos domésticos. De acordo com Almeida; Onuki \& Carneiro, o objetivo central dessa pesquisa é "conhecer e compreender a percepção das elites e do público brasileiro em relação à nossa política externa e à política internacional em geral” (2011: 2).

E, é a partir dessa pesquisa "Brasil, as Américas e o Mundo: opinião pública e política externa", e utilizando o modelo proposto por Wittkopf (1990) para estabelecer uma tipologia para identificar a postura da Opinião Pública e da Opinião da Elite a respeito da política externa brasileira, que, o presente trabalho será pautado, tendo estes dois elementos como sua base. 
Capítulo 2 - Criando uma tipologia da Opinião Pública sobre a Política Externa do Brasil

Um importante trabalho e que será utilizado como referência nessa dissertação foi organizado por Eugene Wittkopf, Faces of Internationalism Public Opinion in American Foreign Policy (1990), aborda os padrões das elites e da massa em relação ao grau de apoio ao envolvimento internacional dos Estados Unidos. De acordo com o autor, a experiência na prolongada e trágica guerra no sul da Ásia, no Vietnã (1955-1963), causou uma fundamental reorientação no pensamento dos líderes políticos e da opinião pública sobre qual seria o papel mais adequado dos EUA no mundo.

Ao analisar pesquisas ${ }^{20}$ realizadas entre os anos de 1974 e 1986, em intervalos de 4 anos, durante a Guerra Fria, o autor demostra que as análises não poderiam ser limitadas à dicotomia 'cooperativa' e 'militarista', ou seja, "as duas faces do internacionalismo" (1990:09). Um mundo bipolarizado, as atitudes com relação ao comunismo, ao uso de tropas norte-americanas e as relações com a União Soviética foram os principais indicadores que distinguiram os favoráveis e opositores a cada tipo de internacionalismo.

Dessa forma, se verificou que, após a Guerra do Vietnã, a população e a elite estadunidense estava dividida não apenas a respeito do grau de envolvimento internacional do país, mas em como deveria ser seu comportamento. A partir da ideia de duas faces do internacionalismo, Wittkopf criou quatro grupos distintos de atitudes ou sistemas de crenças em política externa, e que provaram ser invariavelmente temporal:

\footnotetext{
${ }^{20}$ Surveys sobre opinião pública da elite e da massa, realizada pela Chicago Council on Foreign Relations.
} 
Figura 2.0

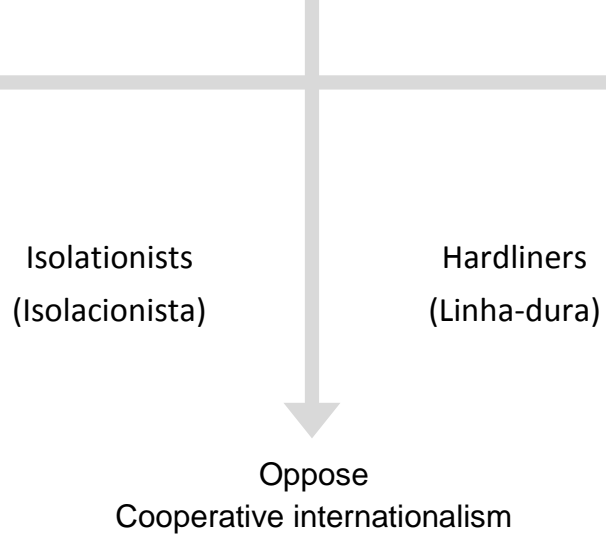

Fonte: Wittkopf, Eugene. 1990

Para Witkkopf (1990), os Internacionalistas são aqueles que apoiam um envolvimento ativo nos assuntos internacionais, favorecendo uma combinação de estratégias conciliatórias e belicosa, ou seja, realiza uma interface entre diplomacia e o uso da força, unindo política de cooperação e militar, sendo totalmente à favor da presença do Estado no cenário internacional. Insolacionistas, por outro lado, se opõe em ambos os tipos de envolvimento internacional (conciliador ou conflituoso), são contrários à participação do país no sistema internacional, independente de sua forma de ação.

Os outros dois grupos, que o autor considera como "internacionalistas seletivas" surgiram na década de 1970. Os "Accommodationists", que foi traduzido como Conciliadores (Soft Power ${ }^{21}$ ), abraçam os princípios da

\footnotetext{
${ }^{21}$ Em "O Futuro do Poder" (2012), o autor Joseph Nye apresenta os conceitos atuais de Soft e Hard Power. Para ele, Soft Power é a habilidade de cooptação, de definir a agenda, de
} 
cooperação internacional, mas rejeitam os elementos do internacionalismo militar, ou seja, prestigia o uso da diplomacia, são favoráveis à cooperação e rejeitam atos belicosos. E, manifestando exatamente o oposto, o último grupo Linha-dura (Hard-Power ${ }^{22}$ ), são totalmente favoráveis ao internacionalismo belicoso e contrários ao cooperativismo.

Os dados das pesquisas realizados por Wittkopf demonstraram que a opinião pública norte-americana estava estruturada a partir dessas tipologias. A distribuição da Opinião da Massa entre os quatros tipos de crenças em Política Externa é descrita pelas dimensões internacionalismo cooperativo e internacionalismo militante.

persuadir e exercer atração positiva. Evidentemente, o Soft Power está mais associado a dois aspectos do poder: de criar agendas e definir quais temas têm relevância no sistema internacional e o de moldar as preferências e interesses de parceiros e rivais. O Hard Power, por outro lado, é o poder de coerção, mais ligado à ideia de que o poder pode se manifestar como a capacidade de impor comportamentos e resultados.

22. O Hard Power, por outro lado, é o poder de coerção, mais ligado à ideia de que o poder pode se manifestar como a capacidade de impor comportamentos e resultados. Nye, O Futuro do Poder, 2012 
Figura 3.1 - distribuição da Opinião da Massa entre os quatro tipos de crenças em Política Externa, 1974 - 1986. (em \%)

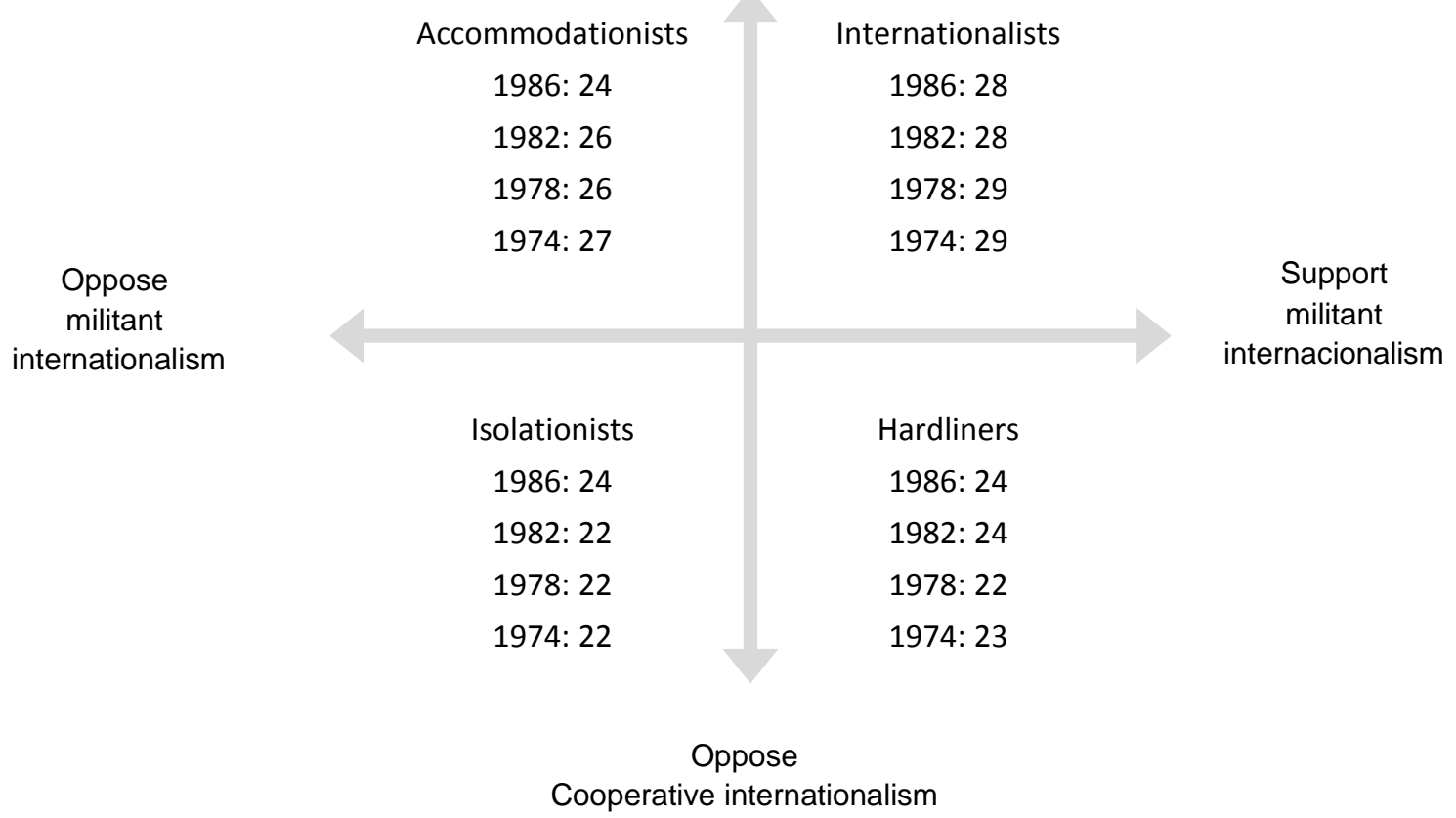

Fonte: Wittkopf, Eugene. 1990

A tabela acima demostra que a população norte-americana manteve-se comprometida com a visão de que os EUA deveriam estar envolvidos nos assuntos mundiais. Pode-se notar que a grande maioria dos entrevistados dividiam-se entre os três grupos de atitude internacionalista, seja de forma mais branda, como os conciliadores, seja de forma mais linha dura. Ao mesmo tempo, fica evidente que o público estava fortemente divido em seus pontos de vista, em como deveria ser o envolvimento do país no sistema internacional. É importante ressaltar que, com a apresentação desses dados, é possível observar que na década de 1970 a população dos Estados Unidos tendia para 
uma orientação mais internacionalista, correspondendo a $28 \%$ das respostas. Uma década depois, de 1980, a tendência permaneceu, apesar de uma leve queda na porcentagem.

\subsection{Tipologia brasileira}

Porém, nas pesquisas realizadas no Brasil, que são utilizadas como base dessa dissertação, a variável "militarista", ou seja, atitude "linhadura/hardpower' não representa a realidade do país. Pode-se indagar que seria por uma tradição diplomática com base na não-intervenção e a busca resoluções pacíficas de conflitos, ou pela estrutura das Forças Armadas brasileira. Para que a análise não seja prejudicada, as tipologias do Wittkopf serão utilizadas como base, porém novas categorias serão criadas, numa escala de grau de importância com determinados temas.

Outra modificação realizada foram os eixos $\mathrm{X}$ e $\mathrm{Y}$ no gráfico de atitude. $\mathrm{Na}$ pesquisa do autor, as bases são militarismo e cooperação, variando de acordo com o grau de aproximação ou distanciamento. Na nova tipologia, quatro questões serão utilizadas como base, sendo duas da Opinião Pública e duas da Opinião de Elite. Os eixos ${ }^{23}$ serão, no caso da primeira, "Direitos Humanos" e "Democracia"; e na segunda, "Participação" e "Democracia". Dessa forma, foram feitos os cruzamentos de duas questões, em ambas as pesquisas, que proporcionaria uma melhor identificação do comportamento do país em relação à política externa. As questões são:

\section{Opinião Pública}

${ }^{23}$ Os eixos "Direitos Humanos" e "Democracia" foram selecionados a partir da pesquisa Opinião Pública - Brasil, Américas e Mundo, de 2011 (em anexo), que poderia demonstrar de forma mais clara, qual deveria ser o comportamento do Brasil no sistema internacional, mais especificamente, quando o assunto esta diretamente ligado à política interna de outro Estado. 
P15. O que você acha que o Brasil deveria fazer com relação a um país no qual os direitos humanos não são respeitados? (1. Deve romper relações diplomáticas com esse país; 2. Deve procurar que organismos, como a ONU, que critiquem esses países; 3. Não deve se envolver em assuntos internos desse país; 4. NS; e 5. NR).

P30. Caso o exército ou um grupo armado de algum país latinoamericano derrubasse um governo democraticamente, você acredita que o Brasil deveria...? (1. Romper relações diplomáticas com o novo governo; 2. Condenar as atitudes tomadas de forma pública, mas sem romper relações diplomáticas; 3. Esperar a reação internacional e então agir; 4. Não fazer nada; 5. NS; e 6. NR)

Dessa forma, o cruzamento entre as duas questão resultou na seguinte tabela ${ }^{24}$ :

Case Processing Summary

\begin{tabular}{|c|c|c|c|c|c|c|}
\hline & \multicolumn{6}{|c|}{ Cases } \\
\hline & \multicolumn{2}{|c|}{ Valid } & \multicolumn{2}{|c|}{ Missing } & \multicolumn{2}{|c|}{ Total } \\
\hline & $\mathrm{N}$ & Percent & $\mathrm{N}$ & Percent & $\mathrm{N}$ & Percent \\
\hline $\begin{array}{l}\text { P15) O que você acha } \\
\text { que o Brasil deve fazer } \\
\text { com relação a um país } \\
\text { no qual os direitos } \\
\text { humanos não são } \\
\text { respeitados? * P30) } \\
\text { Caso o exército ou um } \\
\text { grupo armado de algum } \\
\text { país latino-americano } \\
\text { derrubasse um governo } \\
\text { eleito democraticamente, } \\
\text { você acredita que o Brasil } \\
\text { deveria ...? }\end{array}$ & 1702 & $85,1 \%$ & 298 & $14,9 \%$ & 2000 & $100,0 \%$ \\
\hline
\end{tabular}

${ }^{24}$ A primeira tabela apresenta os casos de missing, que foram retirados para melhor visualização dos dados na segunda tabela. 
P15) 0 que você acha que o Brasil deve fazer com relação a um país no qual os direitos humanos não são respeitados? ^ P30) Caso o exército ou um grupo armado de algum país latino-americano derrubasse um governo eleito democraticamente, você acredita que o Brasil deveria ...? Crosstabulation

\begin{tabular}{|c|c|c|c|c|c|c|c|}
\hline & & & \multicolumn{4}{|c|}{$\begin{array}{l}\text { P30) Caso o exército ou um grupo armado de algum país latino- } \\
\text { americano derrubasse um governo eleito democraticamente, você } \\
\text { acredita que o Brasil deveria ...? }\end{array}$} & \multirow[b]{2}{*}{ Total } \\
\hline & & & $\begin{array}{l}\text { Romper } \\
\text { relações } \\
\text { diplomáticas } \\
\text { com o novo } \\
\text { governo }\end{array}$ & $\begin{array}{l}\text { Condenar as } \\
\text { atitudes } \\
\text { tomadas de } \\
\text { forma pública, } \\
\text { mas sem } \\
\text { rompe }\end{array}$ & $\begin{array}{l}\text { Esperar a } \\
\text { reação } \\
\text { internacional } \\
\text { e então agir }\end{array}$ & $\begin{array}{c}\text { Não fazer } \\
\text { nada }\end{array}$ & \\
\hline \multirow{9}{*}{$\begin{array}{l}\text { P15) O que você acha } \\
\text { que o Brasil deve fazer } \\
\text { com relação a um país } \\
\text { no qual os direitos } \\
\text { humanos não são } \\
\text { respeitados? }\end{array}$} & \multirow{3}{*}{$\begin{array}{l}\text { Deve romper relações } \\
\text { diplomáticas com esse } \\
\text { pais }\end{array}$} & Count & 163 & 166 & 81 & 14 & 424 \\
\hline & & $\%$ of Total & $9,6 \%$ & $9,8 \%$ & $4,8 \%$ & $0,8 \%$ & $24,9 \%$ \\
\hline & & Adjusted Residual & 11,0 &, 8 & $-7,2$ & $-4,8$ & \\
\hline & \multirow{3}{*}{$\begin{array}{l}\text { Deve procurar que } \\
\text { organismos, como a } \\
\text { ONU, que critiquem esse }\end{array}$} & Count & 123 & 337 & 254 & 32 & 746 \\
\hline & & $\%$ of Total & $7,2 \%$ & $19,8 \%$ & $14,9 \%$ & $1,9 \%$ & $43,8 \%$ \\
\hline & & Adjusted Residual & $-3,1$ & 5,7 &, 6 & $-6,2$ & \\
\hline & \multirow{3}{*}{$\begin{array}{l}\text { Não deve se envolver em } \\
\text { assuntos internos desse } \\
\text { país }\end{array}$} & Count & 53 & 137 & 232 & 110 & 532 \\
\hline & & $\%$ of Total & $3,1 \%$ & $8,0 \%$ & $13,6 \%$ & $6,5 \%$ & $31,3 \%$ \\
\hline & & Adjusted Residual & $-6,9$ & $-6,8$ & 6,1 & 11,1 & \\
\hline \multirow[t]{2}{*}{ Total } & & Count & 339 & 640 & 567 & 156 & 1702 \\
\hline & & $\%$ of Total & $19,9 \%$ & $37,6 \%$ & $33,3 \%$ & $9,2 \%$ & $100,0 \%$ \\
\hline
\end{tabular}

Para a realização de uma tipologia da Opinião Pública sobre Política Externa do Brasil, com base em Wittkopf, foi criada uma tabela de condicionantes:

Tipologia

\begin{tabular}{|c|c|c|c|c|c|}
\hline & & Frequency & Percent & Valid Percent & $\begin{array}{c}\text { Cumulative } \\
\text { Percent }\end{array}$ \\
\hline \multirow{13}{*}{ Valid } & 1 & 163 & 8,2 & 9,6 & 9,6 \\
\hline & 2 & 166 & 8,3 & 9,8 & 19,3 \\
\hline & 3 & 81 & 4,1 & 4,8 & 24,1 \\
\hline & 4 & 14 & ,7 & ,8 & 24,9 \\
\hline & 5 & 123 & 6,2 & 7,2 & 32,1 \\
\hline & 6 & 337 & 16,9 & 19,8 & 51,9 \\
\hline & 7 & 254 & 12,7 & 14,9 & 66,9 \\
\hline & 8 & 32 & 1,6 & 1,9 & 68,7 \\
\hline & 9 & 53 & 2,7 & 3,1 & 71,9 \\
\hline & 10 & 137 & 6,9 & 8,0 & 79,9 \\
\hline & 11 & 232 & 11,6 & 13,6 & 93,5 \\
\hline & 12 & 110 & 5,5 & 6,5 & 100,0 \\
\hline & Total & 1702 & 85,1 & 100,0 & \\
\hline Missing & System & 298 & 14,9 & & \\
\hline Total & & 2000 & 100,0 & & \\
\hline
\end{tabular}


Ou seja,

\begin{tabular}{|c|c|c|c|c|}
\hline P15 / P30 & $\begin{array}{l}\text { Romper } \\
\text { relações } \\
\text { diplomáticas } \\
\text { com o novo } \\
\text { governo } \\
\end{array}$ & $\begin{array}{l}\text { Condenar as atitudes } \\
\text { tomadas de forma } \\
\text { pública, mas sem } \\
\text { romper relações } \\
\text { diplomáticas } \\
\end{array}$ & $\begin{array}{l}\text { Esperar a } \\
\text { reação } \\
\text { internacional } \\
\text { e então agir }\end{array}$ & $\begin{array}{l}\text { Não fazer } \\
\text { nada }\end{array}$ \\
\hline $\begin{array}{l}\text { Deve romper relações } \\
\text { diplomáticas com esse } \\
\text { país }\end{array}$ & $\begin{array}{c}1 \\
(163-9,6 \%)\end{array}$ & $\begin{array}{c}2 \\
(166-9,8 \%)\end{array}$ & $\begin{array}{c}3 \\
(81-0,8 \%)\end{array}$ & $\begin{array}{c}4 \\
(14-0,8 \%)\end{array}$ \\
\hline $\begin{array}{l}\text { Deve procurar que } \\
\text { organismos, como a } \\
\text { ONU, que critiquem } \\
\text { esses países }\end{array}$ & $\begin{array}{c}5 \\
(123-7,2 \%)\end{array}$ & $\begin{array}{c}6 \\
(337-19,8 \%)\end{array}$ & $\begin{array}{c}7 \\
(254-14,9 \%)\end{array}$ & $\begin{array}{c}8 \\
(32-1,9 \%)\end{array}$ \\
\hline $\begin{array}{l}\text { Não deve se envolver } \\
\text { em assuntos internos } \\
\text { desses países }\end{array}$ & $\begin{array}{c}9 \\
(53-3,1 \%)\end{array}$ & $\begin{array}{c}10 \\
(137-8,0 \%)\end{array}$ & $\begin{array}{c}11 \\
(232-13,6 \%)\end{array}$ & $\begin{array}{c}12 \\
(110-6,5 \%)\end{array}$ \\
\hline
\end{tabular}

Fonte: tabela criada pela própria autora

1- P15 = Deve romper relações diplomáticas com esse país \& P30 $=$ Romper relações diplomáticas com o novo governo;

2- P15 = Deve romper relações diplomáticas com esse país \& P30 = Condenar as atitudes de forma pública, mas sem romper relações diplomáticas;

3- P15 = Deve romper relações diplomáticas com esse país \& P30 = Esperar a reação internacional e então agir;

4- P15 = Deve romper relações diplomáticas com esse país \& P30 = Não fazer nada;

5- P15 = Deve procurar que organismos, com a ONU, que critiquem esses países \& P30 = Romper relações diplomáticas com o novo governo;

6- P15 = Deve procurar que organismos, com a ONU, que critiquem esses países \& P30 = Condenar as atitudes de forma pública, mas sem romper relações diplomáticas;

7- $\mathrm{P} 15$ = Deve procurar que organismos, como a ONU, que critiquem esses países \& P30 = Esperar a reação internacional e então agir;

8- P15 = Deve procurar que organismos, com a ONU, que critiquem esses países $\& \mathrm{P} 30$ = Não fazer nada;

9- $\mathrm{P} 15=$ Não deve se envolver em assuntos internos desses países \& P30 = Romper relações diplomáticas com o novo governo;

10-P15 = Não deve se envolver em assuntos internos desses países \& $\mathrm{P} 30=$ Condenar as atitudes de forma pública, mas sem romper relações diplomáticas;

11-P15 = Não deve se envolver em assuntos internos desses países \& P30 = Esperar a reação internacional e então agir; 
12-P15 = Não deve se envolver em assuntos internos desses países \& P30 = Não fazer nada.

A partir da tipologia criada por Wittkopf (internacionalista, isolacionista, hardlines/hard power ou conciliador/soft power), nas tabelas 1 e 1.1, e os dados da pesquisa sobre Opinião Pública, especificamente no cruzamento das questões 15 e 30, busca-se entender como essa parcela da sociedade brasileira pode ser caracterizada em relação à política internacional. Porém, os conceitos utilizados por Wittkof serão adaptados conforme a realidade brasileira.

Dois conceitos centrais serão utilizados como base principal: Isolacionista e Internacionalista. No caso do segundo, será subdividido em mais três tipos: Internacionalista Hard Line, Internacionalista Moderado e Internacionalista Soft Line. Para uma melhor visualização, os grupos e subgrupos serão divididos da seguinte forma:

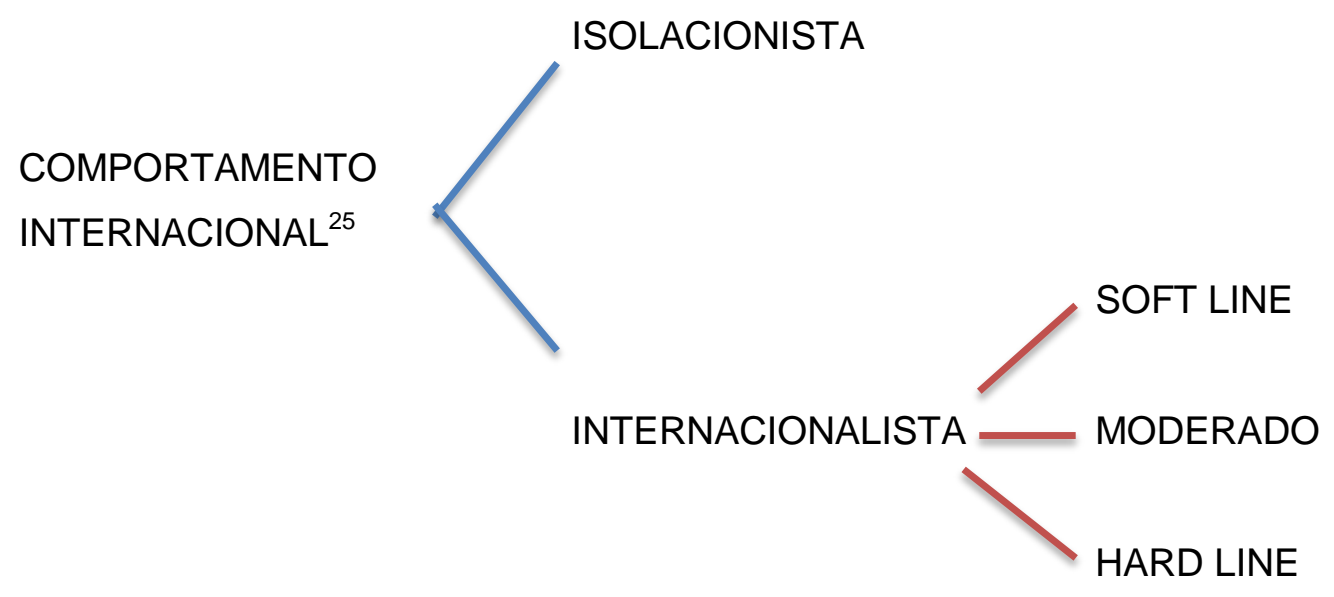

\footnotetext{
${ }^{25}$ Nesse trabalho, os temas que serão utilizados como base para tal classificação são Direitos Humanos e Democracia.
} 
Os dois conceitos principais Isolacionistas e Internacionalistas remete a ideia de não participação e de participação no sistema internacional, respectivamente. Em relação aos três tipos de internacionalistas: linha branda (soft line), moderado e linha dura (hard line). No primeiro caso, uma política externa mais voltada aos princípios da não intervenção dos povos, busca das resoluções através da diplomacia e não uso do poder bélico. Pode-se mencionar a idealização de J. Nye, sobre o Soft Power. Por sinal, essa linha branda é a base cultural e tradicional da Política Externa Brasileira, herança do ministro Barão de Rio Branco (1901 - 1910).

Uma política externa mais linha dura (hard line),que também pode ser remetido á definição da Hard Power, de Nye, defende o rompimento diplomático com um determinado Estado, caso necessário, agindo de forma austera. Historicamente, o Brasil não utiliza uma linha dura em sua política externa. E, no caso de um internacionalismo moderado, seria uma união das duas outras linhas, dura e branda, sendo possível um rompimento em determinados casos e algo mais voltado à diplomacia em outros.

Assim, podemos ter a seguinte tipologia ${ }^{26}$ da Opinião Pública brasileira, em relação aos temas "Direitos Humanos" e "Democracia" e seu comportamento no sistema internacional.

\section{ISOLACIONISTA}

12 - No total, 110 pessoas (6,5\%) acreditam que nas duas situações o país deveria romper relações com o determinado país. Nesse caso, elas podem ser

\footnotetext{
${ }^{26}$ Os números de 1 a 12 representam os grupos de pessoas como resultado de cada cruzamento.
} 
consideradas isolacionistas, ou seja, são contrários à participação do país em assuntos de outros Estados, independente da forma de ação e da conjuntura.

\section{INTERNACIONALISTA HARD LINE}

1- Para 163 dos entrevistados (9,6\%), o país deve romper relações com os Estados que não respeitam Direitos Humanos e a Democracia. Aqui, considera-se o rompimento uma forma mais dura da diplomacia, mesmo não havendo intervenção militar.

\section{INTERNACIONALISTA MODERADO}

2, 3, 5, 6 e 7 - Ao unir as opções condenar, mas não romper e aguardar posição internacional, pode-se classificar esse grupo formado por 961 pessoas, que representa $56,5 \%$ como moderados, pois ao mesmo tempo defendem um país ativo no sistema internacional, porém não com ações mais linha dura em nenhuma das situações questionadas.

\section{INTERNACIONALISTA SOFT LINE}

$4,8,9,10,11$ - Nesses cinco casos, totalizando 468 entrevistados $(27,4 \%)$, de alguma forma defendem a ideia de um país ativo no sistema internacional em um determinado assunto e um isolacionismo em outro. Ou seja, é interessante observar que os grupos $4(14 / 0,8 \%)$ e $8(32 / 1,9 \%)$ dão maior importância à violação dos Direitos Humanos, alegam que o Brasil deve agir, ou rompendo as relações (grupo 4) ou procurando que organismos internacionais se posicionem (grupo 8) e, quando a situação é de desrespeito à democracia, o país não deve agir. E, ao contrário também pode ser verificado, onde os grupos 9 $(53 / 3,1 \%), 10(137 / 8 \%)$ e $11(232 / 13,6 \%)$ tendem a defender um regime 
democrático, ou rompendo relações, ou condenando, mas sem romper ou, até mesmo aguardando reação internacional para, então, agir. Em compensação, acreditam que quando o assunto é Direitos Humanos, o Estado não deve se manifestar.

Além da tipologia realizada acima, pode-se dividir os resultados em duas categorias: pura e híbrida. Na primeira categoria, os grupos 1,7 e 12 representam aqueles que possuem a mesma postura tanto em relação ao desrespeito aos direitos humanos quanto a um golpe de estado num regime democraticamente eleito. Nessa situação, grupo 1, que totaliza 163 pessoas $(9,6 \%)$ são consideradas puras hard line, linha dura ao defenderem rompimento diplomático em qualquer das duas situações. Em seguida, o grupo 7 busca uma política externa mais multilateralista e cooperativa, escolhendo esperar (inclusive a posição da ONU) para depois tomar atitude, sendo assim, com uma postura pura de internacionalismo moderado. E, por último nessa categoria "pura", o grupo 12, com uma posição isolacionista, onde o país não deveria se envolver em assuntos internos de outros Estados. Os demais grupos 2, 3, 4, 5, 6, 8, 9, 10 e 11 pertenceriam a categoria "híbrida", ou seja, sua postura no sistema internacional depende do tema abordado. 
2.2 Relação Variáveis Dependentes e Independentes - caracterizando os grupos tipológicos.

O primeiro passo foi identificar as atitudes da opinião pública, através de duas questões que indicassem as possíveis dimensões do comportamento do Brasil no sistema internacional. A tipologia criada por Wittkopf, e adaptada para a realidade brasileira, definiu, como apresentado anteriormente, quatro grupos de atitude em relação à Política Externa do Brasil: Isolacionista, Internacionalista Soft Power, Internacionalista Conciliador e Internacionalista Hard Power.

A seguir, serão apresentados os resultados dos cruzamentos entre as variáveis independentes pré-selecionadas (sexo, ideologia, faixa etária e escolaridade), com as variáveis dependentes das pesquisas de Opinião Pública. Lembrando que, as questões selecionadas são:

P15. O que você acha que o Brasil deveria fazer com relação a um país no qual os direitos humanos não são respeitados? (1. Deve romper relações diplomáticas com esse país; 2. Deve procurar que organismos, como a ONU, que critiquem esses países; 3. Não deve se envolver em assuntos internos desse país; 4. NS; e 5. NR).

P30. Caso o exército ou um grupo armado de algum país latinoamericano derrubasse um governo democraticamente, você acredita que o Brasil deveria...? (1. Romper relações diplomáticas com o novo governo; 2. Condenar as atitudes tomadas de forma pública, mas sem romper relações diplomáticas; 3. Esperar a reação internacional e então agir; 4. Não fazer nada; 5. NS; e 6. NR) 


\section{Sexo}

\begin{tabular}{|l|c|c|}
\hline \multicolumn{1}{|c|}{ Sexo } & $\mathbf{N}^{\circ}$ Entrevistados & \% \\
\hline Feminino & 1030 & 51,5 \\
\hline Masculino & 970 & 48,5 \\
\hline TOTAL & 2000 & 100 \\
\hline
\end{tabular}

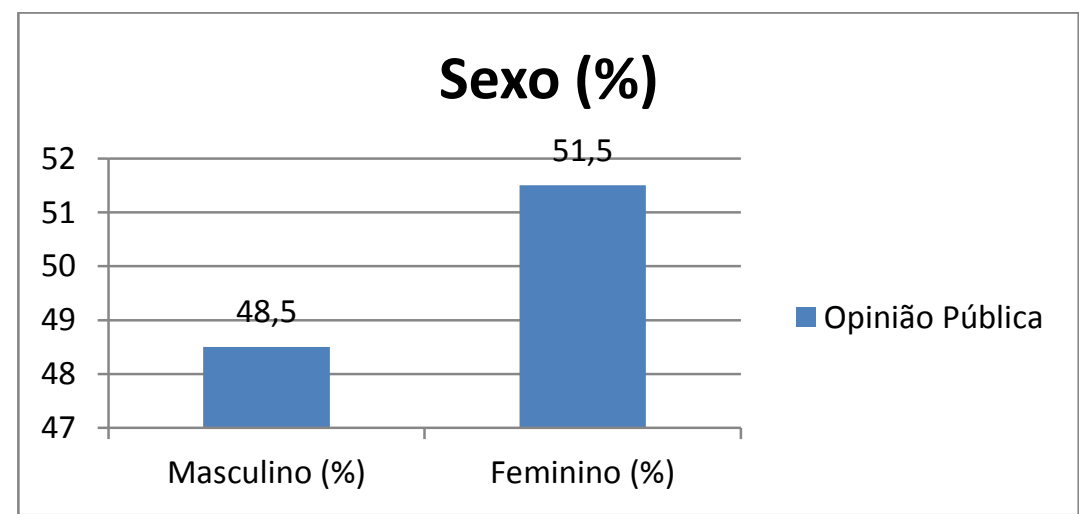

Sexo do Entrevistado ${ }^{*} \mathrm{P}$ 15) 0 que você acha que o Brasil deve fazer com relação a um país no qual os direitos humanos não são respeitados? Crosstabulation

\begin{tabular}{|c|c|c|c|c|c|c|}
\hline & & & \multicolumn{3}{|c|}{$\begin{array}{l}\text { P15) O que você acha que o Brasil deve fazer } \\
\text { com relação a um país no qual os direitos } \\
\text { humanos não são respeitados? }\end{array}$} & \multirow[b]{2}{*}{ Total } \\
\hline & & & $\begin{array}{l}\text { Deve romper } \\
\text { relações } \\
\text { diplomáticas } \\
\text { com esse } \\
\text { país }\end{array}$ & $\begin{array}{c}\text { Deve procurar } \\
\text { que } \\
\text { organismos, } \\
\text { como a ONU, } \\
\text { que critiquem } \\
\text { esse } \\
\end{array}$ & $\begin{array}{l}\text { Não deve se } \\
\text { envolver em } \\
\text { assuntos } \\
\text { internos } \\
\text { desse pais }\end{array}$ & \\
\hline \multirow[t]{4}{*}{ Sexo do Entrevistado } & Masculino & Count & 238 & 376 & 286 & 900 \\
\hline & & $\%$ of Total & $13,2 \%$ & $20,8 \%$ & $15,8 \%$ & $49,8 \%$ \\
\hline & Feminino & Count & 217 & 404 & 288 & 909 \\
\hline & & $\%$ of Total & $12,0 \%$ & $22,3 \%$ & $15,9 \%$ & $50,2 \%$ \\
\hline \multirow[t]{2}{*}{ Total } & & Count & 455 & 780 & 574 & 1809 \\
\hline & & $\%$ of Total & $25,2 \%$ & $43,1 \%$ & $31,7 \%$ & $100,0 \%$ \\
\hline
\end{tabular}

De acordo com o cruzamento apresentado, não há diferenças significantes entre as respostas, no caso da variável independente. Tanto entrevistados do sexo masculino, quando do sexo feminino apresentaram um equilíbrio, com pequena vantagem (masculino: 20,8\% e feminino: $22,3 \%$ ) para um comportamento internacionalista moderado, totalizando $43,1 \%$ das respostas. A maior semelhança ocorre numa postura mais isolacionista, onde $31,7 \%$ das pessoas acreditam que o Brasil não deveria se envolver em 
assuntos de outros Estados. Nesse caso, há, matematicamente, um equilíbrio entre homens e mulher, com 15,8\% e 15,9\% das respostas, respectivamente. E, com uma atitude internacionalista hard line, entre os homens são $13,2 \%$ e entre as mulheres, $12 \%$.

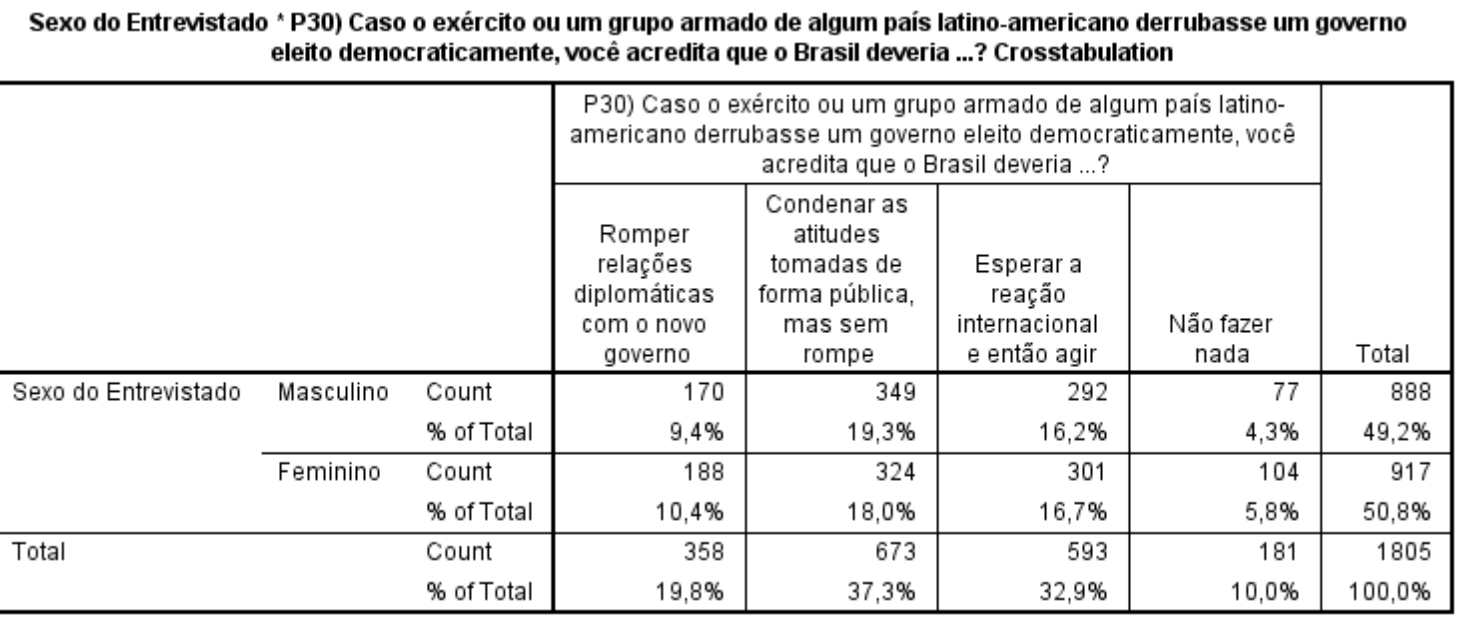

Dessa forma, há algumas diferenças significantes entre as respostas, no caso da variável independente. Tanto entrevistados do sexo masculino, quando do sexo feminino apresentaram um equilíbrio, com pequena vantagem (masculino: 20,8\% e feminino: $22,3 \%$ ) para um comportamento internacionalista moderado, totalizando $37,3 \%$ das respostas. Em comparação e, seguindo na mesma linha, 32,9\% defendem uma postura mais soft line, apresentando uma semelhança entre homens e mulheres, sendo $16,2 \%$ do sexo masculino e $16,7 \%$ do sexo feminino. Com uma atitude internacionalista hard line, entre os homens são 9,4\% e entre as mulheres, 10,4\% dos entrevistados. O comportamento isolacionista é o que representar o menor número das respostas, com apenas $10 \%$ do total, sendo $4,3 \%$ - que representa 77 pessoas do sexo masculino e 5,8\% ou seja, 104 pessoas do sexo feminino.

\section{Faixa Etária}




\begin{tabular}{|l|c|c|}
\hline \multicolumn{1}{|c|}{ Idade } & $\mathbf{N}^{\circ}$ Entrevistados & $\mathbf{\%}$ \\
\hline 18 a 24 anos & 377 & 18,85 \\
\hline 25 a 29 anos & 204 & 10,2 \\
\hline 30 a 39 anos & 392 & 19,6 \\
\hline 40 a 49 anos & 361 & 18,05 \\
\hline 50 a 59 anos & 275 & 13,75 \\
\hline 60 anos ou mais & 391 & 19,55 \\
\hline Total & $\mathbf{2 0 0 0}$ & $\mathbf{1 0 0}$ \\
\hline
\end{tabular}

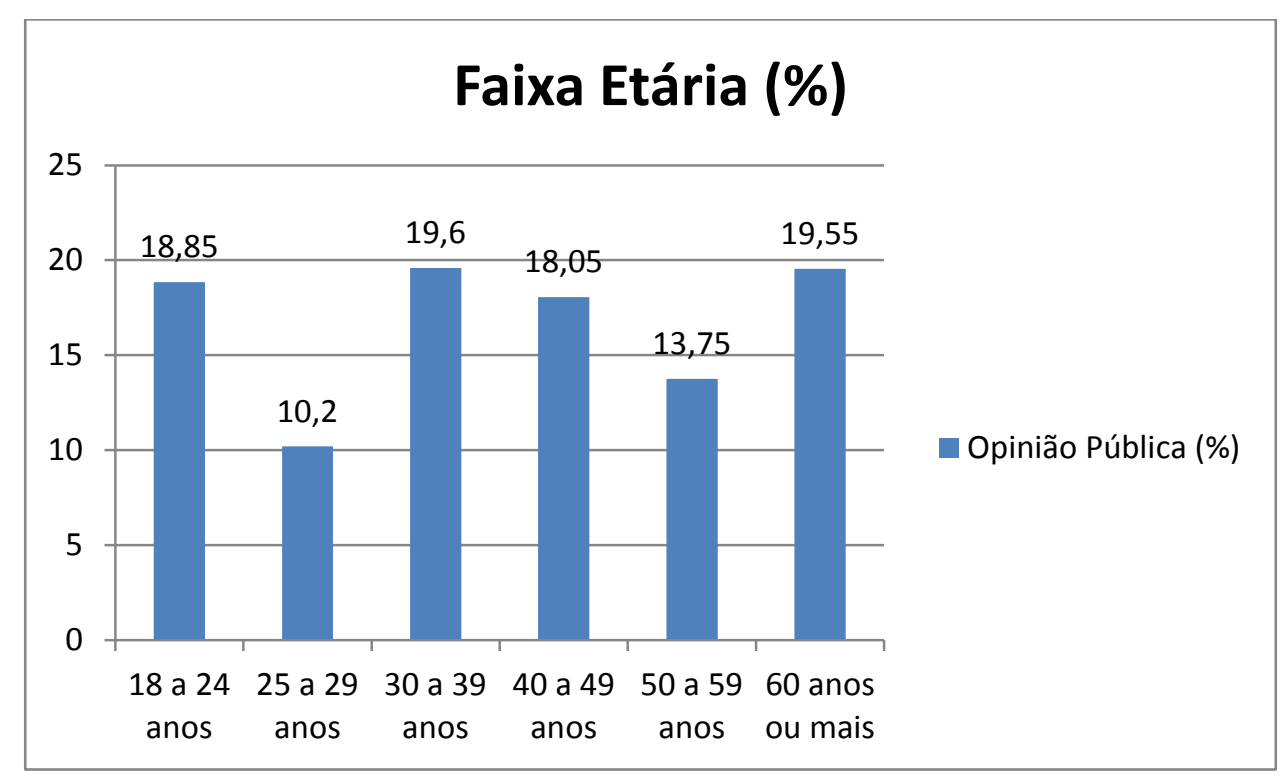


Faixa Etaria * P15) 0 que você acha que o Brasil deve fazer com relação a um país no qual os direitos humanos não são respeitados? Crosstabulation

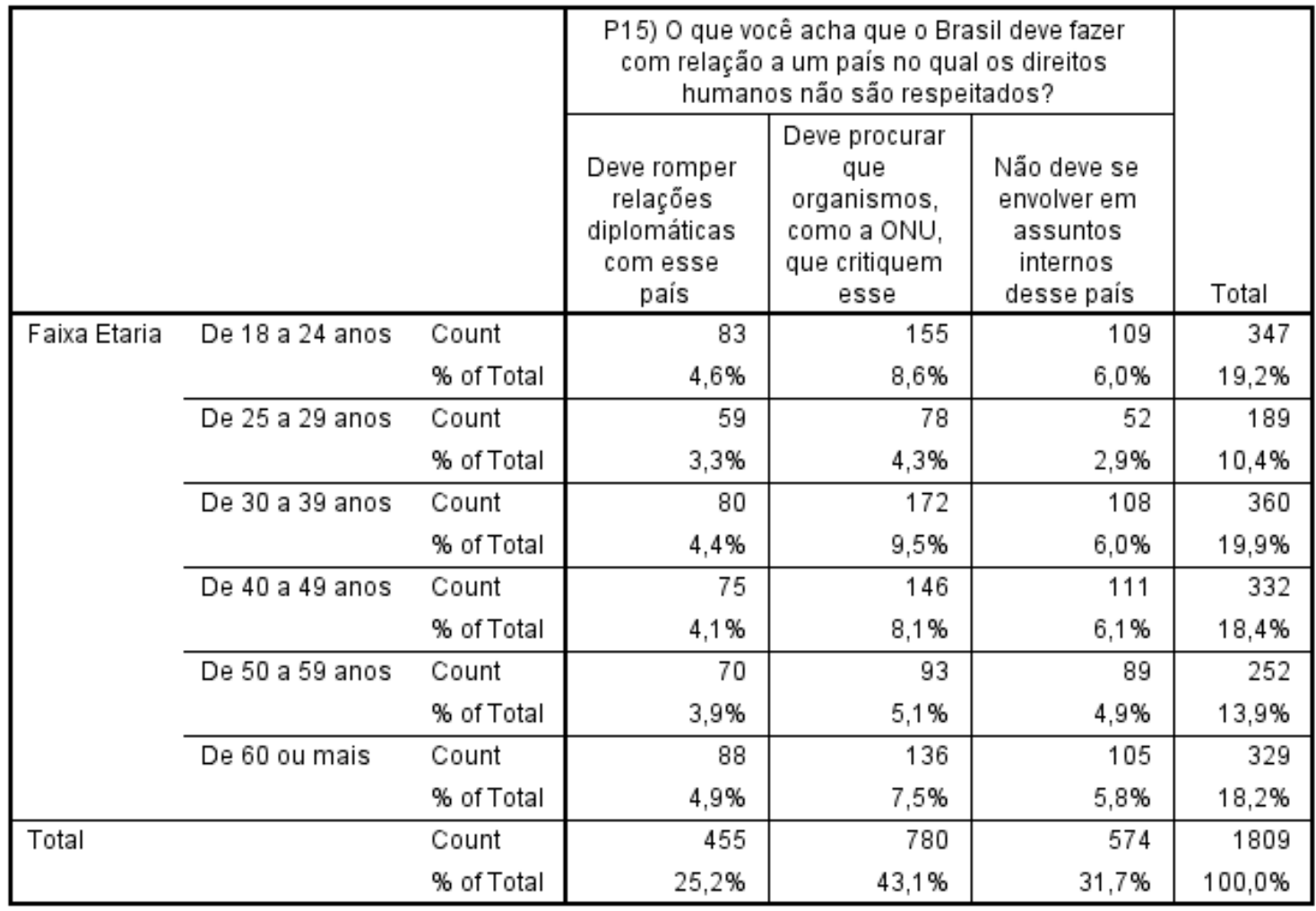

Fonte: Pesquisa "O Brasil, as América e o Mundo" - Ipsos Public Affairs (2011)

Em relação a variável independente, há um equilíbrio entre o número de pessoas em relação à faixa etária. Do total, $43,1 \%$ das pessoas se comportam como internacionalista moderado, sendo escolhido pela maioria nas faixas entre 30 e 39 anos, 18 e 24 anos e 60 anos ou mais, com 9,5\%, 8,6\% e $8,1 \%$, respectivamente. $\mathrm{O}$ destaque fica para $\mathrm{o}$ grupo dos isolacionistas, onde 574 pessoas, equivalente a 31,7\% acreditam que o Brasil não deveria se envolver em assuntos internos de outros Estados. E, ao contrário, com uma postura mais hard line, 25,2\% dos entrevistados que responderam a questão defendem uma ação de rompimento diplomático. 
Faixa Etaria * P30) Caso o exército ou um grupo armado de algum país latino-americano derrubasse um governo eleito democraticamente, você acredita que o Brasil deveria ...? Crosstabulation

\begin{tabular}{|c|c|c|c|c|c|c|c|}
\hline & & & \multicolumn{4}{|c|}{$\begin{array}{c}\text { P30) Caso o exército ou um grupo armado de algum país latino- } \\
\text { americano derrubasse um governo eleito democraticamente, você } \\
\text { acredita que o Brasil deveria ...? }\end{array}$} & \multirow[b]{2}{*}{ Total } \\
\hline & & & $\begin{array}{l}\text { Romper } \\
\text { relaçőes } \\
\text { diplomáticas } \\
\text { com o novo } \\
\text { governo }\end{array}$ & $\begin{array}{l}\text { Condenar as } \\
\text { atitudes } \\
\text { tomadas de } \\
\text { forma pública, } \\
\text { mas sem } \\
\text { rompe }\end{array}$ & $\begin{array}{l}\text { Esperar a } \\
\text { reação } \\
\text { internacional } \\
\text { e então agir }\end{array}$ & $\begin{array}{c}\text { Não fazer } \\
\text { nada }\end{array}$ & \\
\hline \multirow[t]{12}{*}{ Faixa Etaria } & De 18 a 24 anos & Count & 62 & 141 & 111 & 33 & 347 \\
\hline & & $\%$ of Total & $3,4 \%$ & $7,8 \%$ & $6,1 \%$ & $1,8 \%$ & $19,2 \%$ \\
\hline & De 25 a 29 anos & Count & 38 & 70 & 66 & 12 & 186 \\
\hline & & $\%$ of Total & $2,1 \%$ & $3,9 \%$ & $3,7 \%$ & $0,7 \%$ & $10,3 \%$ \\
\hline & De 30 a 39 anos & Count & 76 & 141 & 108 & 29 & 354 \\
\hline & & $\%$ of Total & $4,2 \%$ & $7,8 \%$ & $6,0 \%$ & $1,6 \%$ & $19,6 \%$ \\
\hline & De 40 a 49 anos & Count & 77 & 109 & 109 & 41 & 336 \\
\hline & & $\%$ of Total & $4,3 \%$ & $6,0 \%$ & $6,0 \%$ & $2,3 \%$ & $18,6 \%$ \\
\hline & De 50 a 59 anos & Count & 41 & 94 & 84 & 20 & 239 \\
\hline & & $\%$ of Total & $2,3 \%$ & $5,2 \%$ & $4,7 \%$ & $1,1 \%$ & $13,2 \%$ \\
\hline & De 60 ou mais & Count & 64 & 118 & 115 & 46 & 343 \\
\hline & & $\%$ of Total & $3,5 \%$ & $6,5 \%$ & $6,4 \%$ & $2,5 \%$ & $19,0 \%$ \\
\hline \multirow[t]{2}{*}{ Total } & & Count & 358 & 673 & 593 & 181 & 1805 \\
\hline & & $\%$ of Total & $19,8 \%$ & $37,3 \%$ & $32,9 \%$ & $10,0 \%$ & $100,0 \%$ \\
\hline
\end{tabular}

Em caso de golpe em um governo democraticamente eleito, há uma predominância, também, de uma posição internacionalista moderado, com 673 pessoas, sendo $37,3 \%$ do total. Em todas as faixa etária, a maioria engloba essa postura, sendo as faixas entre 18 e 24 anos e entre 30 e 39 anos em maior número, com 7,8 \% e 141 pessoas em cada. Ou seja, há um empate. Entre os isolacionistas, a faixa de 60 anos ou mais predomina, com 46 pessoas, representando $2,5 \%$ das respostas. $E$, dos que defendem uma postura mais linha dura, a faixa entre os 40 e 49 anos está com uma leve predominância em comparação à faixa dos 30 e 39 anos, com 77 (4,3\%) e 76 $(4,2 \%)$ das respostas respectivamente. 
2 Ideologia (Escala Política)

\begin{tabular}{|l|c|c|}
\hline Escala Política & $\begin{array}{c}\mathrm{N}^{\circ} \\
\text { Respostas }\end{array}$ & $\%$ \\
\hline 1 & 60 & 3 \\
\hline 2 & 50 & 2,5 \\
\hline 3 & 62 & 3,1 \\
\hline 4 & 157 & 7,85 \\
\hline 5 & 344 & 17,2 \\
\hline 6 & 235 & 11,75 \\
\hline 7 & 202 & 10,1 \\
\hline 8 & 177 & 8,85 \\
\hline 9 & 116 & 5,8 \\
\hline 10 & 135 & 6,75 \\
\hline NS & 374 & 18,7 \\
\hline NR & 88 & 4,4 \\
\hline TOTAL & $\mathbf{2 0 0 0}$ & $\mathbf{1 0 0}$ \\
\hline
\end{tabular}

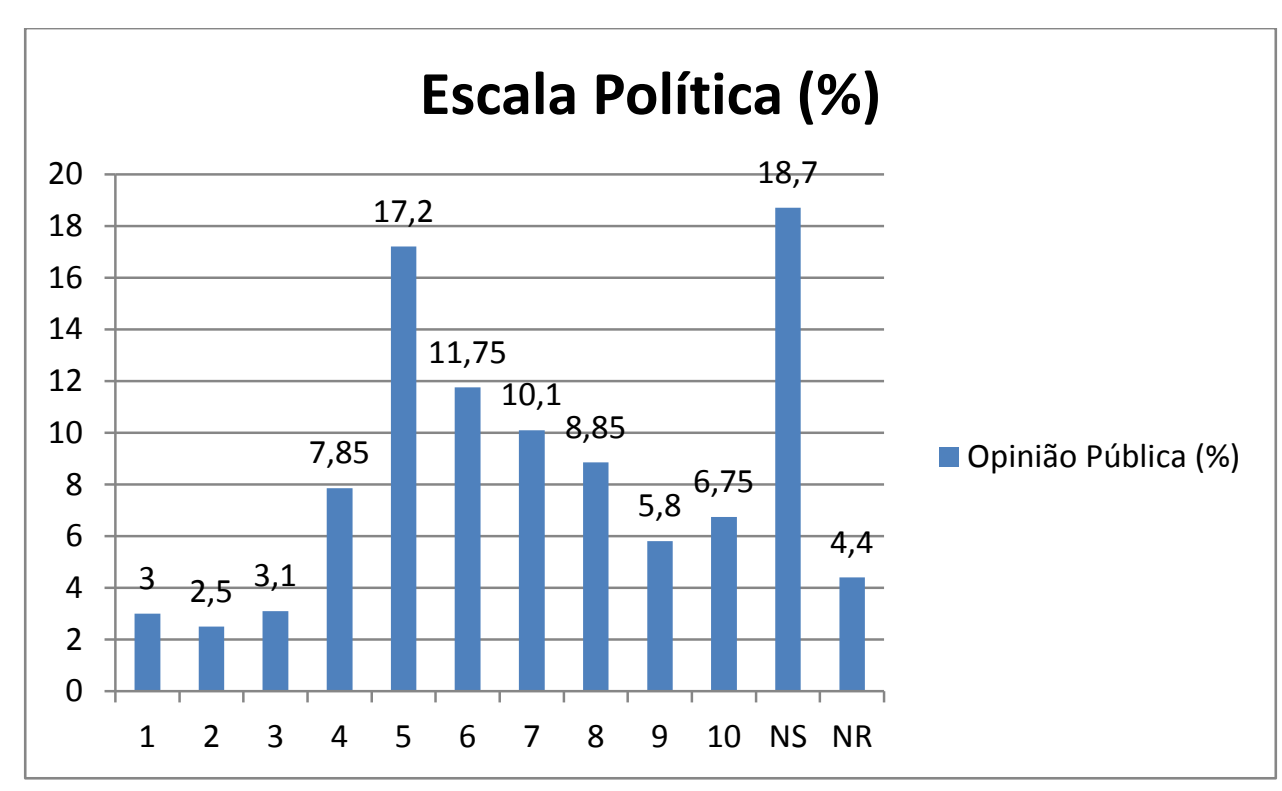

Para uma melhor visualização dos resultados, a escala política foi subdividida em três grupos: esquerda, centro e direita. Dessa forma, os números do intervalo 1e4, foram colocados no grupo esquerda; entre 5 e 6 , centro e, finalmente, entre 7 e 10, considerados de direita. Dessa forma, o cruzamento entre ideologia (esquerda, centro e direita), resultou: 
Ideo_OP * P 15) 0 que você acha que o Brasil deve fazer com relação a um país no qual os direitos humanos não são respeitados? Crosstabulation

\begin{tabular}{|c|c|c|c|c|c|c|}
\hline & & & \multicolumn{3}{|c|}{$\begin{array}{c}\text { P15) O que você acha que o Brasil deve fazer } \\
\text { com relação a um país no qual os direitos } \\
\text { humanos não são respeitados? }\end{array}$} & \multirow[b]{2}{*}{ Total } \\
\hline & & & $\begin{array}{l}\text { Deve romper } \\
\text { relações } \\
\text { diplomáticas } \\
\text { com esse } \\
\text { país }\end{array}$ & $\begin{array}{c}\text { Deve procurar } \\
\text { que } \\
\text { organismos, } \\
\text { como a ONU, } \\
\text { que critiquem } \\
\text { esse }\end{array}$ & $\begin{array}{c}\text { Não deve se } \\
\text { envolver em } \\
\text { assuntos } \\
\text { internos } \\
\text { desse pais }\end{array}$ & \\
\hline \multirow[t]{8}{*}{ Ideo_OP } & Esquerda & Count & 66 & 121 & 110 & 297 \\
\hline & & $\%$ of Total & $3,6 \%$ & $6,7 \%$ & $6,1 \%$ & $16,4 \%$ \\
\hline & Centro & Count & 127 & 239 & 178 & 544 \\
\hline & & $\%$ of Total & $7,0 \%$ & $13,2 \%$ & $9,8 \%$ & $30,1 \%$ \\
\hline & Direita & Count & 160 & 265 & 158 & 583 \\
\hline & & $\%$ of Total & $8,8 \%$ & $14,6 \%$ & $8,7 \%$ & $32,2 \%$ \\
\hline & NS & Count & 102 & 155 & 128 & 385 \\
\hline & & $\%$ of Total & $5,6 \%$ & $8,6 \%$ & $7,1 \%$ & $21,3 \%$ \\
\hline \multirow{2}{*}{\multicolumn{2}{|c|}{ Total }} & Count & 455 & 780 & 574 & 1809 \\
\hline & & $\%$ of Total & $25,2 \%$ & $43,1 \%$ & $31,7 \%$ & $100,0 \%$ \\
\hline
\end{tabular}

O cruzamento acima mostra a distribuição ideológica dos entrevistados, apresentando que não há um padrão nas respostas, ou seja, não se pode afirmar que a posição política, ou ideologia, influencia na opinião sobre o comportamento do Brasil no sistema internacional. Pode-se observar que 780 das pessoas entrevistas (representando 43,1\%), seja de esquerda, centro ou direita defendem que quando o problema é desrespeito aos direitos humanos, o Brasil deveria se comportar de maneira internacionalista, porém de forma softh power, procurando organismos que critiquem tal ação, como a ONU. E, quem mais se encaixa nessa característica são as pessoas que se consideram de direita, sendo 265 comparados aos 239 de centro e 121 pessoas de esquerda.

Merece destaque o grupo dos isolacionistas, representando $31,7 \%$, ou seja, 574 pessoas acreditam que o país não deveria se envolver com assuntos internos de outros países. Nessa categoria, os "centristas" representam 9,8\%, 
do total de $31,7 \%$ dos que encaixam nesse grupo. $E$, entre aqueles que acreditam que o Brasil deveria ter uma ação mais radical, com rompimento de sua relação com outro Estado, totaliza 25,2\%, sendo 8,8\% de direta, 7,0\% de centro e $3,6 \%$ de esquerda.

\begin{tabular}{|c|c|c|c|c|c|c|c|}
\hline & & & \multicolumn{4}{|c|}{$\begin{array}{l}\text { P30) Caso o exército ou um grupo armado de algum país latino- } \\
\text { americano derrubasse um governo eleito democraticamente, você } \\
\text { acredita que o Brasil deveria ...? }\end{array}$} & \multirow[b]{2}{*}{ Total } \\
\hline & & & $\begin{array}{l}\text { Romper } \\
\text { relações } \\
\text { diplomáticas } \\
\text { com o novo } \\
\text { governo }\end{array}$ & $\begin{array}{l}\text { Condenar as } \\
\text { atitudes } \\
\text { tomadas de } \\
\text { forma pública, } \\
\text { mas sem } \\
\text { rompe }\end{array}$ & $\begin{array}{l}\text { Esperar a } \\
\text { reação } \\
\text { internacional } \\
\text { e então agir }\end{array}$ & $\begin{array}{c}\text { Não fazer } \\
\text { nada }\end{array}$ & \\
\hline \multirow[t]{8}{*}{ Ideo_OP } & Esquerda & Count & 55 & 115 & 98 & 28 & 296 \\
\hline & & $\%$ of Total & $3,0 \%$ & $6,4 \%$ & $5,4 \%$ & $1,6 \%$ & $16,4 \%$ \\
\hline & Centro & Count & 105 & 210 & 177 & 52 & 544 \\
\hline & & $\%$ of Total & $5,8 \%$ & $11,6 \%$ & $9,8 \%$ & $2,9 \%$ & $30,1 \%$ \\
\hline & Direita & Count & 122 & 234 & 175 & 52 & 583 \\
\hline & & $\%$ of Total & $6,8 \%$ & $13,0 \%$ & $9,7 \%$ & $2,9 \%$ & $32,3 \%$ \\
\hline & NS & Count & 76 & 114 & 143 & 49 & 382 \\
\hline & & $\%$ of Total & $4,2 \%$ & $6,3 \%$ & $7,9 \%$ & $2,7 \%$ & $21,2 \%$ \\
\hline \multirow[t]{2}{*}{ Total } & & Count & 358 & 673 & 593 & 181 & 1805 \\
\hline & & $\%$ of Total & $19,8 \%$ & $37,3 \%$ & $32,9 \%$ & $10,0 \%$ & $100,0 \%$ \\
\hline
\end{tabular}

É possível observar que 673 das pessoas entrevistas (representando $37,3 \%$, seja de esquerda, centro ou direita defendem que quando o problema é desrespeito aos direitos humanos, o Brasil deveria se comportar de maneira internacionalista, porém de forma moderada, condenando as atitudes, porém sem romper as relações. E, quem mais se encaixa nessa característica são as pessoas que se consideram de direita, sendo 234 comparados aos 210 de centro e 115 pessoas de esquerda.

Em relação ao grupo dos isolacionistas, 10\% dos entrevistados, ou seja, 181 pessoas acreditam que o país não deveria se envolver com assuntos internos de outros países. Nessa categoria, os "centristas" e "direitistas" representam 2,9\% cada, do total de $10 \%$ dos que encaixam nesse grupo. E, 
entre aqueles que acreditam que o Brasil deveria ter uma ação mais radical, com rompimento de sua relação com outro Estado, totaliza $19,8 \%$, sendo $6,8 \%$ de direta, $5,8 \%$ de centro e $3 \%$ de esquerda.

\section{Escolaridade}

\begin{tabular}{|l|r|r|}
\hline \multicolumn{1}{|c|}{ Escolaridade } & $\mathrm{N}^{\circ}$ Entrevistados & \multicolumn{1}{c|}{$\%$} \\
\hline Analfabeto/Primário Completo & 402 & $\mathbf{2 0 , 1}$ \\
\hline Primário completo & 470 & $\mathbf{2 3 , 5}$ \\
\hline Ginásio incompleto & 260 & 13 \\
\hline Ginásio completo & 236 & 11,8 \\
\hline Colegial incompleto & 102 & 5,1 \\
\hline Colegial completo & 317 & 15,85 \\
\hline Universitário incompleto & 103 & 5,15 \\
\hline Universitário completo ou + & 110 & 5,5 \\
\hline Total & $\mathbf{2 0 0 0}$ & $\mathbf{1 0 0}$ \\
\hline
\end{tabular}

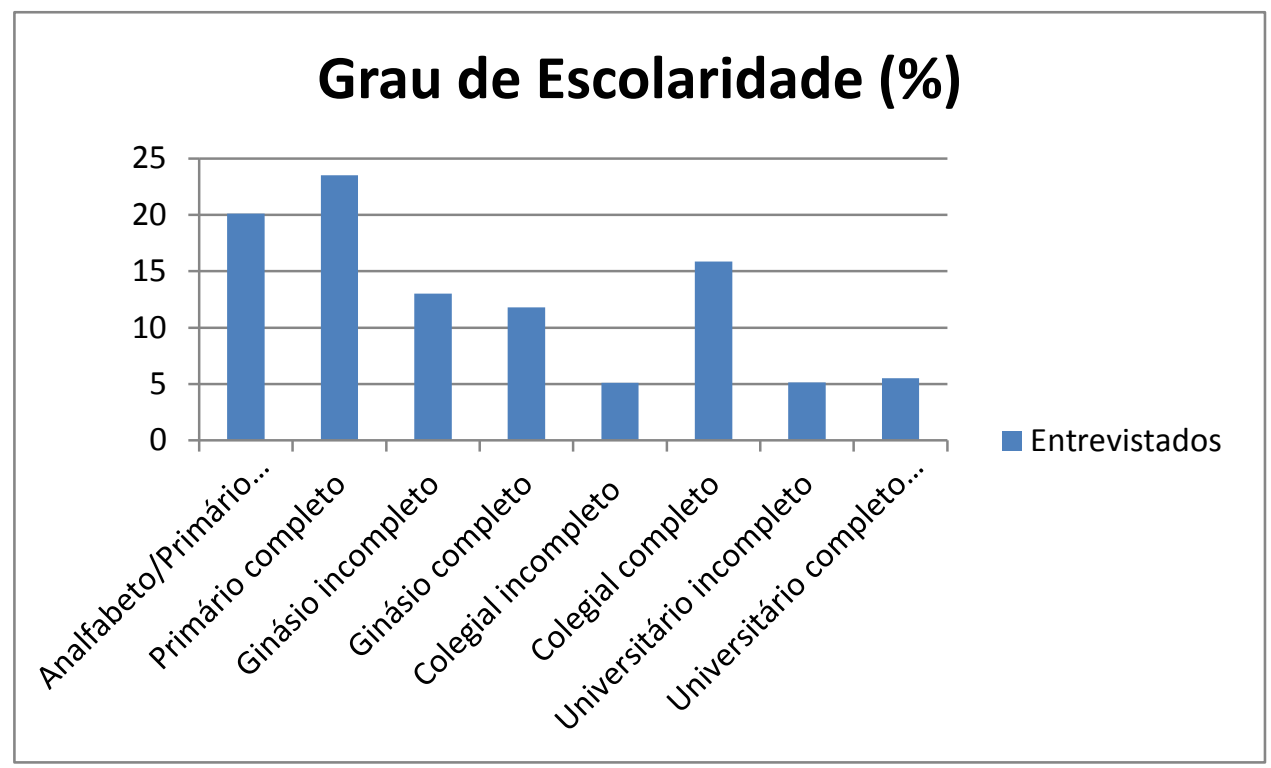


Grau de Instrução do Entrevistado * P15) 0 que você acha que o Brasil deve fazer com relação a um país no qual os direitos humanos não são respeitados? Crosstabulation

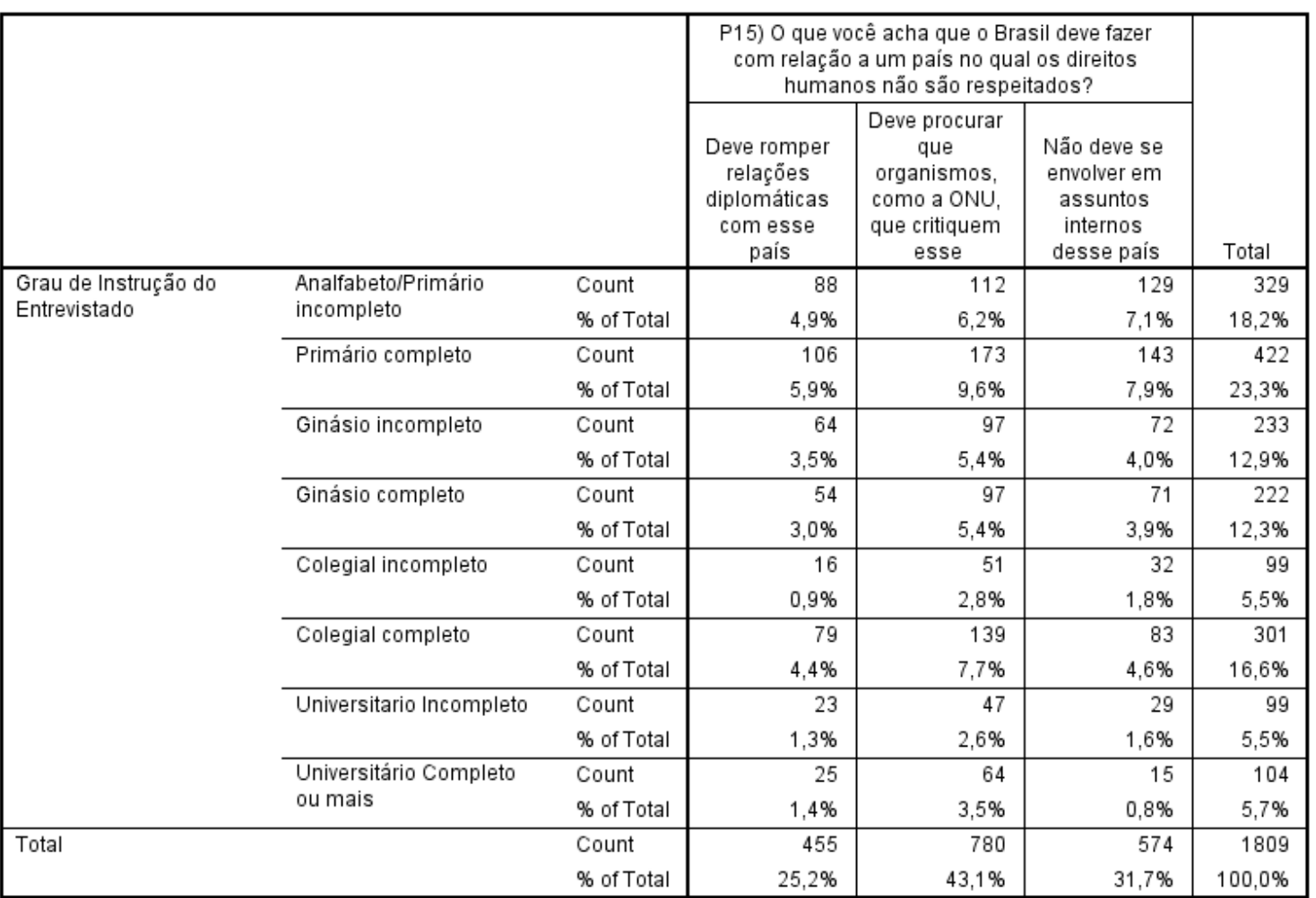

O propósito do cruzamento é entender ser há influência do grau de escolaridade do entrevistado sobre o comportamento do Brasil em caso de desrespeito aos direitos humanos em outro Estado. É interessante perceber que a maioria dos entrevistados não completou o ginásio ${ }^{27}$, representando $54,4 \%$ do total, e, apenas $5,7 \%$ concluíram o ensino superior. Entre os que possuem menor grau de escolaridade (analfabeto/ primário incompleto, primário completo e ginásio incompleto) 344 pessoas (19,0\%) acreditam que o Brasil deveria ter um comportamento mais isolacionista, ou seja, não deve se envolver em assuntos internos de outro país. Entre os com maior grau de instrução, ou seja, superior incompleto e completo, 6,1\% (138 pessoas) defendem um comportamento internacionalista moderado. E, entre os com ginásio completo e colegial completo, são 288 pessoas que também

\footnotetext{
${ }^{27}$ Ginásio - abrange de 6a a 8a série do ensino fundamental.
} 
consideram uma posição moderada. Nesse caso, há uma predominância de uma postura internacionalista moderada.

Grau de Instrução do Entrevistado ^ $\mathrm{P} 30$ ) Caso o exército ou um grupo armado de algum país latino-americano derrubasse um governo eleito democraticamente, você acredita que o Brasil deveria ...? Crosstabulation

\begin{tabular}{|c|c|c|c|c|c|c|c|}
\hline & & & \multicolumn{4}{|c|}{$\begin{array}{l}\text { P30) Caso o exército ou um grupo armado de algum país latino- } \\
\text { americano derrubasse um governo eleito democraticamente, você } \\
\text { acredita que o Brasil deveria ...? }\end{array}$} & \multirow[b]{2}{*}{ Total } \\
\hline & & & $\begin{array}{l}\text { Romper } \\
\text { relações } \\
\text { diplomáticas } \\
\text { com o novo } \\
\text { governo }\end{array}$ & $\begin{array}{l}\text { Condenar as } \\
\text { atitudes } \\
\text { tomadas de } \\
\text { forma pública, } \\
\text { mas sem } \\
\text { rompe }\end{array}$ & $\begin{array}{l}\text { Esperar a } \\
\text { reação } \\
\text { internacional } \\
\text { e então agir }\end{array}$ & $\begin{array}{l}\text { Não fazer } \\
\text { nada }\end{array}$ & \\
\hline \multirow{16}{*}{$\begin{array}{l}\text { Grau de Instrução do } \\
\text { Entrevistado }\end{array}$} & \multirow{2}{*}{$\begin{array}{l}\text { Analfabeto/Primário } \\
\text { incompleto }\end{array}$} & Count & 57 & 115 & 109 & 50 & 331 \\
\hline & & $\%$ of Total & $3,2 \%$ & $6,4 \%$ & $6,0 \%$ & $2,8 \%$ & $18,3 \%$ \\
\hline & \multirow[t]{2}{*}{ Primário completo } & Count & 75 & 149 & 149 & 46 & 419 \\
\hline & & $\%$ of Total & $4,2 \%$ & $8,3 \%$ & $8,3 \%$ & $2,5 \%$ & $23,2 \%$ \\
\hline & \multirow[t]{2}{*}{ Ginásio incompleto } & Count & 56 & 97 & 56 & 27 & 236 \\
\hline & & $\%$ of Total & $3,1 \%$ & $5,4 \%$ & $3,1 \%$ & $1,5 \%$ & $13,1 \%$ \\
\hline & \multirow[t]{2}{*}{ Ginásio completo } & Count & 45 & 80 & 73 & 16 & 214 \\
\hline & & $\%$ of Total & $2,5 \%$ & $4,4 \%$ & $4,0 \%$ & $0,9 \%$ & $11,9 \%$ \\
\hline & \multirow[t]{2}{*}{ Colegial incompleto } & Count & 19 & 33 & 38 & 9 & 99 \\
\hline & & $\%$ of Total & $1,1 \%$ & $1,8 \%$ & $2,1 \%$ & $0,5 \%$ & $5,5 \%$ \\
\hline & \multirow[t]{2}{*}{ Colegial completo } & Count & 68 & 112 & 102 & 16 & 298 \\
\hline & & $\%$ of Total & $3,8 \%$ & $6,2 \%$ & $5,7 \%$ & $0,9 \%$ & $16,5 \%$ \\
\hline & \multirow[t]{2}{*}{ Universitario Incompleto } & Count & 16 & 35 & 39 & 11 & 101 \\
\hline & & $\%$ of Total & $0,9 \%$ & $1,9 \%$ & $2,2 \%$ & $0,6 \%$ & $5,6 \%$ \\
\hline & \multirow{2}{*}{$\begin{array}{l}\text { Universitário Completo } \\
\text { ou mais }\end{array}$} & Count & 22 & 52 & 27 & 6 & 107 \\
\hline & & $\%$ of Total & $1,2 \%$ & $2,9 \%$ & $1,5 \%$ & $0,3 \%$ & $5,9 \%$ \\
\hline \multirow{2}{*}{\multicolumn{2}{|c|}{ Total }} & Count & 358 & 673 & 593 & 181 & 1805 \\
\hline & & $\%$ of Total & $19,8 \%$ & $37,3 \%$ & $32,9 \%$ & $10,0 \%$ & $100,0 \%$ \\
\hline
\end{tabular}

Em relação ao grau de instrução dos entrevistados e a questão sobre um golpe contra um governo democraticamente eleito. Como na análise anterior, é interessante perceber que a maioria dos entrevistados que responderam a questão não completou o ginásio, representando $54,6 \%$ do total, e, apenas $5,9 \%$ concluíram o ensino superior. Entre os que possuem menor grau de escolaridade, 344 pessoas (19,0\%) acreditam que o Brasil deveria ter um comportamento mais isolacionista, ou seja, não deve se envolver em assuntos internos de outro país. Entre os com maior grau de instrução, superior incompleto e completo, 11,5\% (208 pessoas) defendem um comportamento internacionalista moderado. Há um maior equilíbrio entre os com ginásio completo e colegial completo, onde 145 pessoas, equivalente a 8,8\% também consideram uma posição moderada. Porém, do mesmo grau de 
escolaridade, 111 pessoas, 7,8\% acreditam numa posição mais linha branda. Nesse caso, também há uma predominância, com 673 pessoas, representando $37,3 \%$ do total, de uma postura internacionalista moderada. 
Conclusão

Em um momento onde os regimes democráticos se consolidam e se multiplicam, a opinião pública, que coincide em boa medida, com o eleitorado, passou a fazer parte dos questionamentos de estudiosos da política externa, preocupados em diferenciar as forças influentes na definição de ações externas tomadas pelo governo. Essa agenda de pesquisa vem ampliando, principalmente no Brasil.

A primeira geração de estudos de análise de política externa, com base realista, propunha uma metodologia por meio do levantamento de dados empíricos, permitindo estabelecer modelos causais com único fator, nos quais a política externa era explicada pelo interesse nacional, como definida pelos tomadores de decisão, de acordo com a posição do país no sistema internacional. A passagem para a segunda geração resultou numa combinação de condicionantes internas e externas. E é nesse momento que há um aperfeiçoamento dos métodos de pesquisas, sobretudo, quando está relacionado à aplicação de surveys, permitindo compreender a percepção dos cidadãos.

Análises empíricas, utilizando surveys, no campo da política externa, teve destaque com o conjunto de trabalhos coordenados pelo Chicago Council of Foreign Relations - CCFR, a partir de 1974. A obra de Eugene R. Wittkopf, Faces of Internacionalism, Public Opinion and Foreign Policy (1990), reune resultados de quase uma década de pesquisas promovidas pelo CCFR, merece destaque. Outra importante referência, sob liderança de James Rosenau e em parceria com Ole Holsti, teve inicio na década de 1970, é o 
Projeto Liderança em Política Externa (FPLP - Foreign Policy Leadership Project), com o objetivo acompanhar a opinião dos líderes norte-americanos em relação à política externa, utilizando a aplicação sistemática de surveys de opinião com as elites, como políticos, empresários, militares, sindicatos, igrejas, acadêmicos).

A análise da Opinião Pública se revela como uma opção de estudos para os interessados em análise de Política Externa. Em regimes democráticos, há evidências suficientes de que os governos utilizam a Opinião Pública como decision imput na implementação de políticas públicas, economômicas/comerciais e, atualmente, em política externa. Apesar de não sofrer influência direta no processo eleitoral, é um ótimo indicador da aceitação e, assim, da eficácia das ações do governo.

Recentemente, as pesquisas sobre a relação da Opinião Pública são divididas em duas visões diferentes: a visão cética (pessimista) se encaixando no modelo pluralista, partindo do princípio de uma diferença entre um público atento numericamente pequeno e um público de massa muito maior. E do outro, uma visão otimista, que defende a ideia de uma Opinião Pública coerente, razoavelmente informada e a influência depende do contexto e do tema discutido. A primeira possuiria conhecimento suficiente para segurar visualizações coerentes sobre assuntos externos; e o segundo grupo seria mal informado, instável e propenso a mudanças irracionais de opinião.

Nesse modelo pluralista, Gabriel Almond seria o grande precursor dessa linha, além de nomes como Walter Lippman, Ole Hosti e teóricos realistas e neo-realistas, como Hans Morgenthau e John Mearsheimer. Para eles, a 
opinião pública da minoria, além de ser irracional e instável, é volátil, incoerente e com baixa ou nenhuma influência, principalmente em questões de política externa. Para os pensadores que defendem um viés positivo da Opinião Pública, principalmente em regimes democráticos estão nomes como Robert Shapiro, Benjamin Page, Lawrence Jacobs, Eugene Wittkopf, entre outros.

Em relação ao Brasil, as pesquisas de opinião pública tem se tornado, cada vez mais, uma importante ferramenta analítica, inclusive em temas relacionados à política externa. Vale notoriedade a pesquisa "Brasil, as Américas e o Mundo: Opinião Pública e Política Externa", sob coordenação geral do projeto Las Américas y el Mundo, realizada pelo Centro de Investigación y Decencia Económicas - CIDE (México).

Esse projeto internacional buscou compreender as percepções e atitudes do público e das elites sobre os temas internacionais, captando sua reação às mudanças internacionais e seus impactos domésticos. $E$, foi a partir dessa pesquisa "Brasil, as Américas e o Mundo: opinião pública e política externa", e utilizando o modelo proposto por Wittkopf (1990) para estabelecer uma tipologia para identificar a postura da Opinião Pública e da Opinião da Elite a respeito da política externa brasileira, que, o presente trabalho foi pautado.

O trabalho realizado por Eugene Wittkopf, Faces of Internationalism Public Opinion in American Foreign Policy (1990), aborda os padrões das elites e da massa em relação ao grau de apoio ao envolvimento internacional dos Estados Unidos. Após a Guerra do Vietnã, a população e a elite estadunidense estava dividida não apenas a respeito do grau de envolvimento internacional do 
país, mas em como deveria ser seu comportamento. A partir da ideia de duas faces do internacionalismo, Wittkopf criou quatro grupos distintos de atitudes ou sistemas de crenças em política externa, e que provaram ser invariavelmente temporal: Internacionalistas, Isolacionistas, Conciliadores (Soft Power), Intervencionistas (Hard Power).

O primeiro grupo são pessoas que defendem maior envolvimento do país em assuntos internacionais, combinando estratégias conciliatórias e belicosas. Os Isolacionistas, por outro lado, se opõe em ambos os tipos de envolvimento internacional (conciliador ou conflituoso), ou seja,são contrários à participação do país no sistema internacional. Os "Accommodationists", que foi traduzido como Conciliadores (Soft Line), abraçam os princípios da cooperação internacional, mas rejeitam os elementos do internacionalismo militar, ou seja, prestigia o uso da diplomacia. E, o último grupo Intervencionista (Hard Line), são totalmente favoráveis ao internacionalismo belicoso e contrários ao cooperativismo.

No caso do Brasil e para adaptar à realidade do país, novos grupos de atitude formam criados, com base na tipologia de Wittkof: Isolacionista, Internacionalista Hard Line, Internacionalista moderado e Internacionalista Soft Line. Os dois conceitos principais Isolacionistas e Internacionalistas remete a ideia de não participação e de participação no sistema internacional, respectivamente.

No primeiro caso, entre os internacionalistas, uma política externa mais voltada aos princípios da não intervenção dos povos, busca das resoluções através da diplomacia e não uso do poder bélico. Pode-se mencionar a 
idealização de J. Nye, sobre o Soft Power. Por sinal, essa linha branda é a base cultural e tradicional da Política Externa Brasileira, herança do ministro Barão de Rio Branco (1901 - 1910).

Uma política externa mais linha dura (hard line),que também pode ser remetido á definição da Hard Power, de Nye, defende o rompimento diplomático com um determinado Estado, caso necessário, agindo de forma austera. Historicamente, o Brasil não utiliza uma linha dura em sua política externa. E, no caso de um internacionalismo moderado, seria uma união das duas outras linhas, dura e branda, sendo possível um rompimento em determinados casos e algo mais voltado à diplomacia em outros.

Os cruzamentos apresentaram que há uma predominância do internacionalismo moderado nas respostas, tanto no caso de violação dos direitos humanos quanto em caso de golpe contra um presidente democraticamente eleito. Em seguida, uma postura mais internacionalista soft line, mostrando que a Opinião Pública apresenta a mesma linha que a diplomacia brasileira vem adotando ao longo dos anos.

Normalmente, os estudos em Política Externa se limitam a entender sua agenda, instituição e seus decisores. Essa pesquisa apresenta um primeiro passo para realizar outra forma de análise da Política Externa e da Opinião Pública, a luz do instrumento da tipologia, sugerida por Wittkopf. 
Referências bibliográficas:

ALBIG, William. Modern Public Opinion. New York/ Toronto / London: McGrawHill Book Company, Inc., 1956

ALBUQUERQUE, José Augusto Guilhon. As orientações e percepções da elite sobre a atuação externa do Brasil, Relatório da Pesquisa "Percepção das Elites e da Sociedade sobre as relações externas do Brasil", NUPRI, 2001

ALBUQUERQUE, José A. Guilhon at all. Percepções das Elites do Cone Sul sobre as Relações Internacionais do Brasil. Texto para discussão $n^{\circ} 693$, Brasília: IPEA, 1999.

ALLPORT, Floyd H. Toward a Science of Public Opinion. In: Public Opinion Quartely, $\mathrm{n}^{\circ}$ 1, janeiro 1937. pp. $7-23$

ALMEIDA, Maria Hermínia T; ONUKI, Janina \& CARNEIRO, Leandro Piquet. Brasil, as Américas e o Mundo: Opinião Pública e Política Externa. Imprensa Oficial, s/d.

Disponível

em:

http://www.usp.br/iri/documentos/brasil americas mundo.pdf

ALMOND, Gabriel. The American People and Foreign Polícy. New York, NY: Praeger Publisher, 1950

BENTHAM, Jeremy. On the Liberty of Press and Public Discussion, 1821. Disponível em: http://www.la.utexas.edu/research/poltheory/bentham/bsp/index.htm (Acesso em: 07.12.2014)

BLUMER, Herbert. A Massa, o Público e a Opinião Pública. In: COHN, Gabriel. Comunicação e Indústria Cultural. São Paulo: Companhia Editora Nacional e Editora da USP, 1971. pp. 177 - 186

BISHOP, George. The Illusion of Public Opinion: Fact and Artifact in American Public Opinion Polls. Lahnham, MD: Rowman and Litllefield, 2005. 
BOBBIO, Norberto. Teoria das Elites. In: BOBBIO, N; MATTEUCCI, N; PAQUINO,G. Dicionário de Política. Brasília: Ed. UnB e Imprensa Oficial, 2004. 5ª edição, pp.585-391.

BOBBIO, Norberto. Opinião Pública. In: BOBBIO, N; MATTEUCCI, N; PAQUINO, G. Dicionário de Política. Brasília: Ed. UnB e Imprensa Oficial, 2004. $5^{\mathrm{a}}$ edição, pp. 842-845.

BOURDIEU, Pierre. A Opinião Pública não existe. PDF. Disponível em: http://evoluireducacional.com.br/wp-content/uploads/2012/08/21979592-

Bourdieu-A-opiniao-publica-nao-existe.pdf Acesso em: 14.10.2014

BREWER, Paul; GROSS, Kimberly. ADAY, Sean \& WILLNAT, Lars. International trust and Public Opinion about World Affairs. In: American Journal of Political Science. V. 48, n 1, 2004. pp. 93 - 109.

BRYCE, James. The American Commonwealth, vol. 1, 1888. Disponível em: http://oll.libertyfund.org/titles/809 (Acesso em: 07.12.2014)

BRYCE, James. The American Commonwealth, vol. 2, 1888. Disponível em: https://archive.org/stream/americancommonw14brycgoog\#page/n4/mode/2up (Acesso em: 07.12.2014)

BURSTEIN, Paul. The impact of Public Opinin on Public Policy: a review and an agenda. In: Political Research Quarterly, vol. 56, n 1, Mar, 2003. pp. 29 - 40

CASARÕES, Guilherme S. P. A mídia e a política externa no Brasil de Lula. In: Austral: Revista Brasileira de Estratégia e Relações Internacionais, vol. 1, $\mathrm{n}^{\circ} 2$, Jul-Dez, 2012. pp. 211-236

CERVI, Emerson Urizzi. Opinião Pública e Política no Brasil: o que o brasileiro pensa sobre política e porque isso interessa à democracia. Rio de Janeiro, IUPERJ, 2006. Tese de doutorado.

CERVO, Amado L. \& BUENO, Clodoaldo. História da Política Exterior do Brasil. Brasília: Ed. UnB, 2011. 
CHAMPAGNE, Patrick. Formar a Opinião. Petrópolis, Vozes: 1998

CHITTICK, Willian O; BILLINGSLEY, Keith R \& TRAVIS, Rick. A threedimensional model of American foreign policy beliefs. In: International Studies Quartely,n³9, 1995. pp. 313-331

CONVERSE, Philip E. Information Flow and the Stability of Partisan Attitudes. In: The Public Opinion Quartely. Vol. 26, n 4, 1962. pp. 578-599

. The nature of belief systems in mass publics. In:

Critical Review: A Journal of Politics and Society,18:1-3, 1964. pp.1-74

CORTELL, Andrew. Understanding the domestic impact of international norms: a research agenda. In: International Studies Review, n², 2000. pp. 65-47

CORTELL, Andrew \& DAVIS, James W. How do international institutions matter? The domestic impact of international rules and norms. In: Internacional Studies Quartely, n 40, 1996. pp. 451-478

DAHL, Robert. Um prefácio à teoria democrática. Rio de Janeiro:Zahar, 1977.

DANESE, Sérgio. Diplomacia Presidencial. Rio de Janeiro: Topbook, 1999.

DEUTSCH, Karl W. The Analysis of International Relations. Englewood Cliffs, N.J. Prentice Hall, 1968.

DULCl, Octávio Soares. As elites políticas. In: AVELAR, Lúcia; CINTRA, Antônio Octávio. Sistema Político Brasileiro: uma introdução. São Paulo; Rio de Janeiro: Fundação Konrad-Adenauer; Fundação Unesp, 2004.

EICHENBERG, Richard. "Domestic preferences and Foreign Policy cumulation and confirmation in the study of public opinion". In: Mershon International Studies Review, vol. 42, 1998. pp 97-105. 
FARIA, Carlos Aurélio Pimenta de. Opinião Pública e política externa: insulamento, politização e reforma na produção da política exterior do Brasil. In: Revista Brasileira de Política Internacional, vol. 51, n² 2, 2008. pp. 80-97.

FIGUEIREDO, Rubens \& CERVELLINI, Silvia. Contribuições para o conceito de opinião pública. In: Opinião Pública, vol. III, n 3, dezembro, 1995. pp. 171-185

FONSECA Jr, Gelson. A legitimidade e outras questões internacionais. São Paulo: Ed. Paz e Terra, 1998.

FOYLE, Douglas C. Public Opinion and Foreign Policy: elite beliefs as a Mediating Variable. In: InternationalStudies Quartely, vol. 14, 1997. pp.141-169

GASPARY, William R. The Mood Theory: a study of public opinion and foreign policy. In: The American Political Science Review, vol. 64, n 2, Jun, 1970. pp.536-547

GIDEON, Rose. Neoclassical Realism and Theories of Foreign Policy. In: World Politics, Vol. 51, No. 1 (Oct.), Cambridge University Press. 1998. pp. 144172.

GLYNN, Carroll J; HERBST, Susan; O'KEEFE, Garrett J; SHAPIRO, Robert \& LINDEMAN, Mark. Public Opinion. Westview Press, 2004

GOLDSTEIN, Judith \& KEOHANE, Robert O. Ideas and Foreig Policy: beliefs, institutions and political change. Ithaca/London: Cornell university Press, 1993.

GOODIN, Robert E. The Oxford Handbook of Political Science. Oxford: Oxford University Press, 2008.

GRAHAM, Thomas W. Public Opinion and U.S. Foreign Policy Decision Making. In: DEESE, David A. The New Politics of American Foreign Policy. New York, St. Martin's Press, 1994. pp.190-215.

HABERMAS, Jürgen. Comunicação, opinião pública e poder. In: COHN, Gabriel. Comunicação e Indústria Cultural. São Paulo: Companhia Editora Nacional e Editora da USP, 1971. pp. 287 - 200 
HERMANN, Charles F. Changing Course: When governments choose to redirect Foreign Policy. In: International Studies Quarterly, vol. 34, 1990. pp. 3-21

HIRST, Mônica; LIMA, Maria Regina Soares. Contexto Internacional, Democracia e Política Externa. In: CARDIM, Carlos Henrique; HIRST, Mônica (Org.). Soberania e Cultura Política: Brasil-Argentina. Brasília: IPRI/FUNAG, 2003. pp.407-432.

HIRST, Mônica \& PINHEIRO, Letícia. A Política Externa do Brasil em dois tempos. In: Revista Brasileira de Política Internacional, vol. 38, n 1, 1995. pp 523.

HOLSTI, Ole R. International Politics: a framework for analysis. New Jersey: Prentice Hall, 1992.

HOLSTI, Ole R. Public Opinion and American Foreign Policy. Michigan: The University of Michigan Press, 1996.

HOLSTI, Ole R. Public Opinion and Foreig Policy: Challenges to the AlmondLippmann Consensus Mershon Series: Research Programs and Debates. In: International Studies Quarterly, n³6, 1992. pp. 439 - 466

HOLSTI, Ole R. \& ROSENAU, James N. The domestic and Foreign Policy beliefs of American Leaders. In: Jornal of Conflict Resolution, $n^{\circ} 32$, June, 1988. pp.284-294.

HOLZHACKER, Denilde Oliveira. Atitudes e percepções das elites e da população sobre a política externa brasileira nos anos 90. USP - 2006 (tese de doutorado)

As atitudes e opiniões da população a respeito das relações externas do Brasil. USP - 2002 (dissertação de mestrado). 
HURWITZ, Jon \& PEFFLEY, Mark. How are Foreign Policy Attitudes Structured? A Hierarchical Relations. In: The American Political Science Review, v. 81, n4, 1987. pp. $1099-1120$.

INGLEHART, Ronald. Public Opinion and Regional Integration. In: International Organization, vol. 24, n 4, 1970. pp. 764-795

Instituto de Relações Internacionais, Universidade de São Paulo (IRI/USP) Relatório Brasil, as Américas e o mundo: opinião pública e política externa. (2010-11).2011. Disponível em: http://www.usp.br/iri/documentos/brasil americas mundo.pdf

ISERNIA, Pierangelo, JUHÁSZ, Zoltán \& RATTINGER, Hans. Foreign Policy and the Rational Public in Comparative Perspective. In: The Journal of Conflict Resolution, vol. 46, n², Apr. 2002. pp. 201-224

KANT, Immanuel. A Paz Perpetua. Porto Alegre: L\&PM, 1989.

KAPLAN, Abraham \& LASSWELL, Harold. Poder e Sociedade. Brasília: Ed. UnB, 1979.

KNECHT, T. \& WEATHERFORD, W.S. Public Opinion and Foreign Polícy: The Stages of Presidential Decision Making. In: International Studies Quarterly, vol. 50, n³, Sep, 2006. pp. $705-727$.

LAMOUNIER, Bolivar. Ouvindo o Brasil: uma análise da opinião pública brasileira hoje. São Paulo, Idesp, 1992. pp.1992.

LIMA, Maria Regina Soares. Política doméstica determina atuação diplomática. In: Carta Internacional, vol. 4, $n^{\circ}$ 35, fev, 1996. pp 5-6.

LIPPMANN, Walter. Opinião Pública. Rio de Janeiro: Vozes, 2010. 2a Edição. . The Phantom Public. New York: Harcourt, 1925.

LOBELL, S.; RIPSMAN, N. \& TALLIAFERRO, J. Neoclassical Realism, the State and Foreign Policy. Cambrigde, 2009. 
MARINHEIRO, Mateus Rodrigues. Opinião Pública como um decision input em Política Externa: um fenômeno estável, mensurável e previsível. IRI - USP, 2012.

MARX, Karl \& ENGELS, Friedrich. A ldeologia Alemã. Martins Fontes: São Paulo, 2002.

MILLS, C. Wright. A Elite do Poder. $3^{\mathrm{a}}$ ed. Rio de Janeiro: Zahar Editores, 1972.

MORGUENTHAU, Hans J. A política entre as nações: a luta pelo poder e pela paz. São Paulo; Brasília: Imprensa Oficial do Estado de São Paulo; Universidade de Brasília, 2003.

NEACK, Laura. The New Foreign Policy - power seeking in a globalized era. Rowan \& Littlefield Publishers, Inc. 2008.

NYE, Joseph S. O futuro do poder. Benvirá, São Paulo: 2012

NYE, Joseph S. Cooperação e conflito nas Relações Internacionais. São Paulo: Ed. Gente, 2009.

OLIVEIRA, Amâncio J. \& ONUKI, Janina. Eleições, Política Externa e Política. Revista de Sociologia e Política, n²7, Curitiba, 2006.

OLIVEIRA, Henrique Altemani. Política Externa Brasileira. São Paulo: Ed. Saraiva, 2005.

PAGE, Benjamim. Public Opinion and Foreign Policy. Chicago, University of Chicago Press, 1997.

PAGE, Benjamim \& BARBARAS, Jason. Foreign Policy gaps between Citizen and Leaders. In: International Studies Quartely, vol. 44, 2000. pp.339-364.

PAGE, Benjamim \& SHAPIRO, Robert. Effects of public opinion on policy. American Political Science Review, vol. 77, n 1, 1983. pp.175-190.

PASCAL, Georges. Compreender Kant. Ed. Vozes: Rio de Janeiro, 2005. 
POWLICK, Philip \& KATZ, Andrew. Defining the American Public Opinion/Foreign Policy Nexus. In: Mershon International Studies Review. V. 42, no 1, 1998. pp. 29-61.

RISSE - KAPPEN, Thomas. Public Opinion, Domestic Structure and Foreign Policy: Liberal Democracies. In: World Politics, n 43, 1991. pp. 470 - 512

RITTBERGER, Volker. Approaches to the Study of Foreign Policy Derived from International Relations Theories. University of Tübingen, Center for International Relations/Peace and Conflict Studies, Institute for Political Science, 2004.

ROSENAU, James. Public Opinion and Foreign Policy. New York: Randon House, 1972. - The domestic sources of foreign policy. New York: Free Press, 1967.

REUS-SMIT, Christian \& SNIDAL, Duncan. The Oxford Handbook of International Relations. Oxford: Oxford University Press, 2008.

SARTORI, Giovani. Partidos e Sistemas Partidários. São Paulo: Zahar Editora, 1982.

SCHUMPETER, Joseph A. Capitalismo, Socialismo e Democracia. Rio de Janeiro: Editora Fundo de Cultura, 1961.

SHAPIRO, Robert $Y$ \& PAGE, Benjamin I. Foreign Policy and the Rational Public. In: The Journal Conflict Resolution. Vol. 32, n² 2, jun, 1988. pp. 211-247.

SILVEIRINHA, Maria João. Opinião Pública. In: RUBIM, Antonio A.C. Comunicação e Política - conceitos e abordagens. EDUFBA e Unesp: Salvador, 2004. pp. 409-449.

SHAPIRO, Robert \& PAGE, Benjamin. Foreign Policy and the Rational Public. In: The Journal of Conflict Resolution. V. 32, n 2, 1988. pp. 211- 247. 
SMITH, Steve. Foreign Policy - theories, actors and cases. Oxford University Press, New York, 2008.

SOUZA, Amaury de. A Agenda Internacional do Brasil - a política externa brasileira de FHC a Lula. Rio de Janeiro: Elsevier/CEBRI, 2009

TARDE, Gabriel. A Opinião e as Massas. São Paulo: Martins Fontes, 1992.

TOCQUEVILLE, Alexis de. A Democracia na América. Belo Horizonte: Ed. Itatiaia; São Paulo: EdUSP, 1987.

VIGEVANI, Tullo \& CEPALUNI, Gabriel. A Política Externa de Lula da Silva: Autonomia pela Diversificação. In: Contexto Internacional, vol. 29, $\mathrm{n}^{\circ} 2$, julho/dezembro. Rio de Janeiro, 2007. pp. 273 -335

WITTKOPF, Eugene R. Faces of Internacionalism - Public Opinion and American Foreign Policy. Duke University Press, Durkhan and London; 1990 . On the Foreign Policy beliefs of the American People: a critique and some evidence. In: International Studies Quarterly. V. 30, 1986. pp. $425-445$ 